




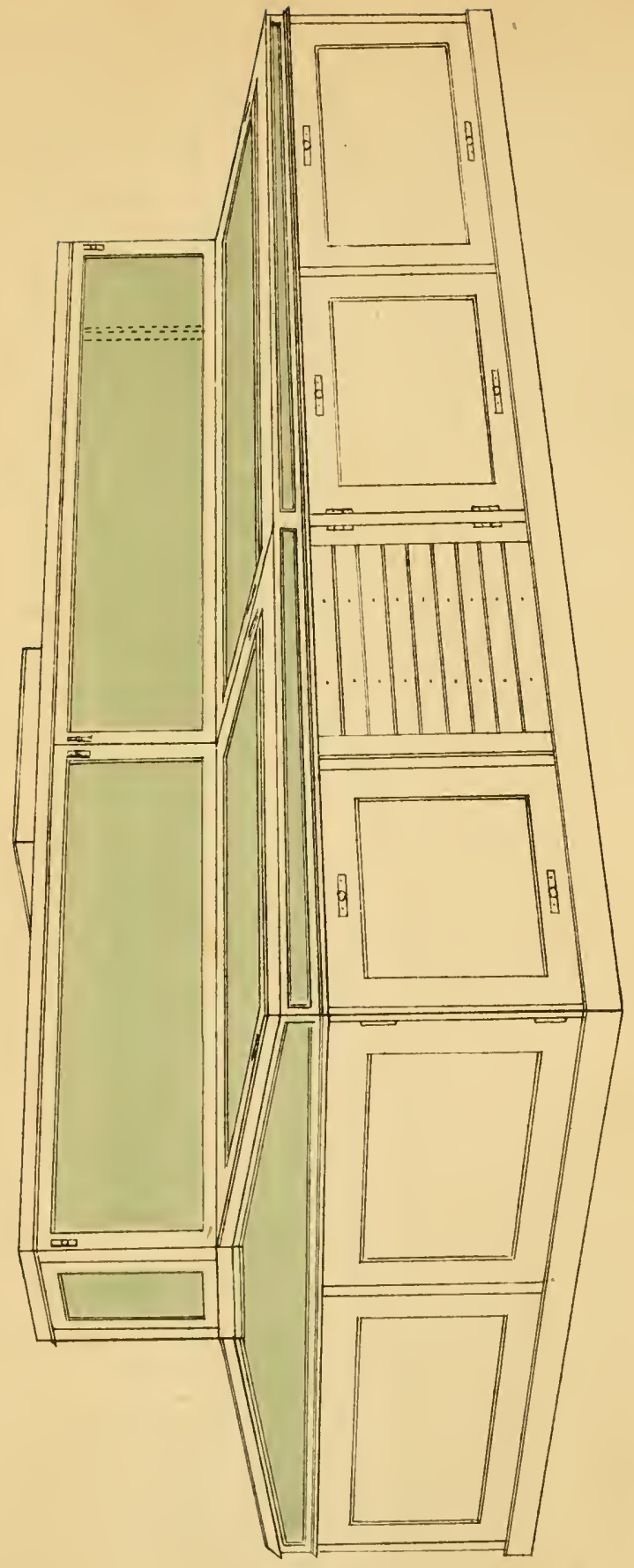




\section{SYNOPSIS}

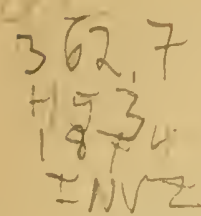

OF AN ARRANGEMENT OF

\section{INVERTEBRATE ANIMALS IN THE}

FREE PUBLIC MUSEUM OF $\mid$ LIVERPOOL; WITH

\section{INTRODUCTION;}

BY THE

Rev. HenRy H. HIGGins, M.A., Cambridge, FOR THE LAST FIFTEEN YEARS A MEMBER OF THE COMMITTEE OF THE TOWN COUNCIL FOR THE MANAGEMENT OF THE LIVERPOOL FREE PUBLIC LIBRARY, MUSEUM, AND GALLERY OF ART.

READ BEFORE THE LITERARY AND PHILOSOPHICAL SOCIETY OF LIVERPOOL, OCTOBER, 1873.

\section{LIVERPOOL :}

PRINTED BY D. MARPLES, MELVILL CHAMBERS, LORD STREET. 



\section{INTRODUCTION.}

IN October, 1861, when the Natural History Collections presented to the Town of Liverpool by the Grandfather of the present Earl of Derby were removed from Duke Street to the building which they now occupy, the question arose, how should the Museum be made as fully as possible to answer the requirements of the population by whom it was to be supported, under the provisions of the Library and Museum Act.

The Curator, Mr. Moore, whose valuable services are well known and highly appreciated, having on his hands, besides the duties of general superintendence, the re-arrangement of the extensive series of Mammalia and Birds, together with preparations for the reception of a similar series of Fishes and Reptiles, availed himself of my offer of assistance in obtaining and arranging a collection of Invertebrate Animals, our stock of which at that time included little beyond some corals and a few very miscellaneous specimens.

The accommodation available for the proposed collection consisted of the central areas of a suite oi five rooms, 27 feet in breadth, the total length being 250 feet. Space was thus provided for 20 table cases, each 10 feet long, set transversely.

One important point was therefore settled by the shape of the building. The series had to be conformed to a linear arrangement. In some respects this was a serious disadvan-

NoTr. -The substance of the greater part of this Introduction appeared in Nature, Jan. 12 and April 20, 1871.

$a$ 
tage. The classes of invertebrate animals cannot well be represented in a single ascending or descending series. Probably it would not be possible on any symmetrical plan to assign to them their proper positions relatively to each other: but some palpable incongruities might be avoided by the use of table-cases on a ground-plan resembling a genealogical tree, one proposed form of which is represented by a diagram in a work published by Professor Rolleston. (See opposite page.)

The importance of a suitable ground-plan for cases in museums seems to be much under-rated. When a class of students visit a museum frequently, the localities of cases containing special groups become indelibly impressed upon the memory. This might be turned to good account.

In preparing the first scheme of the collection, it seemed essential that plain and moderately simple printed deseriptions of the life history of the animals should accompany the specimens: therefore, as it was clearly impossible to describe every genus, it became necessary to fix on some mode of associating in groups a number of examples to which the descriptions might apply. Such divisions as "classes" and "orders" were manifestly too large; whilst "families" varied from a single genus, including a solitary species, to an army of more than a thousand genera, - c.g., the Linnaan families Cerambycide and Curculionida in the Coleoptera. It was with some regret that the idea of attaching a readable sketch to each division of a given rank in recent systems of classification was rolinquished, but it was found to be impracticable; and the life history sketch thus beame the foundation of the arrangement eventually adopted.

Whether it might bo a few species, or a genus, or a family, or an order, that scemed to afford suitable scope for a page of readable and instructive matter, it was decided 
TABULAR VIEW OF aLL tHe CLASSES IN the ANIMAL KINGDOM, from "Forms of Animal Life," by Professor Rolleston, F.R.S. It will be seen on inspection that, with the exception of the elevation of the Classes in Vurues for the sake of keeping the great Annulose division together, the plan of the Synopsis very nearly coincides with that of the following Table.

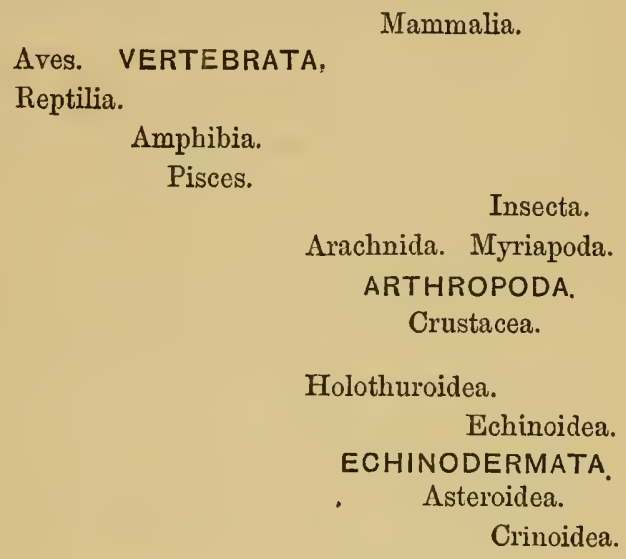

Mammalia.

Aves. VERTEBRATA,

Reptilia.

Amphibia.

Pisces.

Insecta.

Arachnida. Myriapoda.

ARTHROPODA.

Crustacea.

Holothuroidea.

Echinoidea.

ECHINODERMATA.

Asteroidea.

Crinoidea.

Cephalopoda.

Pteropoda.

Gasteropoda.

MOLLUSCA. Lamellibranchiata.

Tunicata.

Brachiopoda.

Polyzoa.

Annulata. Gepliyrea.

VERMES.

Rotifera.

Nematelminthia.

Ctenophora.

Platyelminthia

\section{CELENTERATA.}

Anthozoa.

Hydrozoa.

Spongiadæ. Infusoria.

PROTOZOA.

Rhizopoda.

Gregarinæ. 
that, throughout the entire Collection, such a group should be segregated, so as to form the unit of the series. Eventually, in order that the sketches, which it was proposed to print for that purpose on tablets, might all be in positions where they could conveniently be read, it was found to be expedient that each group or unit should occupy an equal space; and as the blocks on which the table cases rested were to be fitted up with trays or drawers, twelve of which would occupy the table case without loss of room, these trays or drawers were adopted as the receptacles and boundaries of the groups.

The drawers measured 27 inches in length by 16 inches in breadth, and their number in the 20 table cases when completed would be 240 . Then arose the problem how best to divide the 28 Classes of Invertebrate Animals into 240 groups, each of which should be capable of affording materials for a biological notice, such as might be read with interest by any intelligent visitor.

The entire plan of the table cases, and the limits of many of the groups, were committed to writing before any considerable advance had been made in procuring specimens. In one respect this circumstance was found to be very advantageous-our desiderata were at once well defined. It was an object that each of the groups should be illustrated by carefully selected specimens; and until this could be attained, other acquisitions need not be sought for. In making purchases such an object, steadily kept in view, exercises a powerful influence against the seductive attractions of "great bargains," which often turn out to be great misfortunes to a museum. Moreover, in accepting donations it is sometimes convenient to be able to refer to a fixed plan. Where room is scanty, as in most museums, nothing is more subversive of order, or more fatal to an instructive arrangement, than the 
gift of a collection, coupled with a stipulation that it must be displayed in some special way. It is far better to forego the possession even of a valuable series of "specimens, than to sacrifice order for their sake.

The number of groups, 240, will no doubt appear to have been determined simply as a matter of convenience. To a certain extent this is true. It is also true that after a careful reference to the best accessible authorities on each of the Invertebrate Classes, in which much assistance was afforded me by the many valuable scientific works in the Free Public Library of Liverpool, it seemed probable that most of the prominent forms in all the classes might be exhibited in pairs, with their names and localities attached in large and legible characters, in an area less than 1,000 square feet; and that they might conveniently be disposed in 240 groups, occupying 20 table-cases. For these the suite of rooms above referred to afforded ample accommodation.

Four table-cases contain the Protozoa and the Ceruenterata. Seven are given to the Molluscoida and MouLUSCA. Two are occupied by the sub-kingdom ANnuloida, including Echinodermata and Scolecida. Three are given to Annelida and Crustacea. Four cases hold the MrriaPODA, Arachnida, and Insecta. For constant exhibition to the public the series as thus constituted may be regarded as quite sufficiently extensive.

It is hardly necessary for me to point out the difficulties and disadvantages which must arise in the course of an attempt to form a collection in which the whole of the invertebrate classes are divided into a given number of equal groups. If all very distinct forms are to be exhibited, some groups must be heterogeneous in composition, but not necessarily very many. Such forms as Pycnogonum, Forficula, and Sagitta may have to appear as associated with other not 
viii.

very closely allied forms; but the printed tablet may explain the circumstances under which they occupy their position, and render the disadvantage simply a negative one, namely, that in such instances the arrangement cannot afford much help to the memory. It is, on the other hand, one of the peculiar advantages of the plan that the tray or drawer containing an entire group can, with the utmost facility, be removed to be re-arranged, to illustrate a lecture, or to occupy a different position in the series.

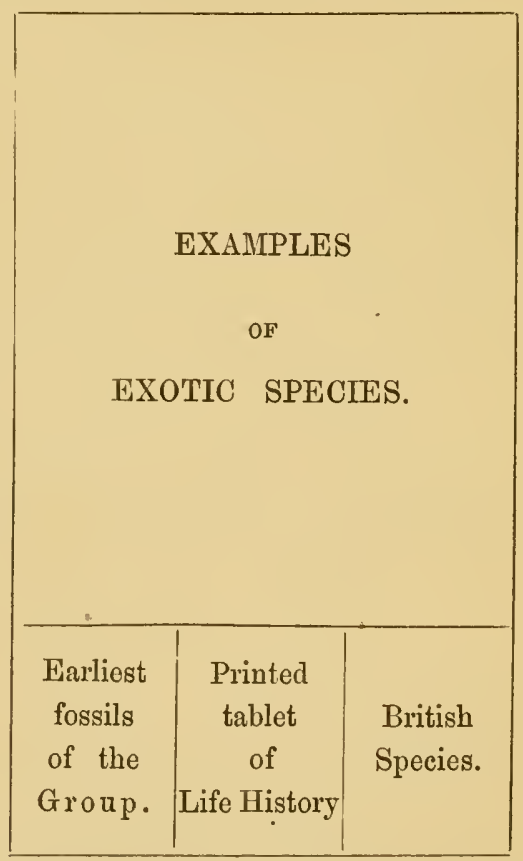

Plan of a Group on a scale of $\frac{1}{8}$ th lin.

In the present unsatisfactory condition of systematic Zoology, probably the only thoroughly scientific mode of conveying information respecting an assemblage of organic forms 
is that adopted by Professor Huxuey, Professor Rolleston, and others, of describing completely a single included species; but this method seems more suited for students than for a mixed company, such as have visited our Institution since October, 1861, during which period the admissions to the Liverpool Museum have exceeded 5,000,000.

The following is the plan of arrangement adopted, in connexion with each group. Wherever circumstances permit, the plan for each group includes, (1) A printed schedule. (2) Exotic species.

(3) British representatives.

(4) The printed tablet. (5) Earliest fossils. (6) Diagrams and other illustrations. (7) Species and varieties on a more extended scale.

(1) The schedule, of which an example follows, is printed in large type, and is attached, conspicuously, to the drawer.

\section{Group 222.}

Sub-Krngdon - Annulosa, Skeleton external, ringed.

Province - Arthropoda, Limbs jointed.

Class - Insecta, Legs six.

Sub-Crass - Metabola, Transformations complete.

Order - Lepidoptera, Wings with scales.

Sub-order - Rhopalocera, Horns clubbed at the apex.

Famrly - Papilionidae Middle nerve of fore-wing four-branched.

The next sub-division appears, not on the schedule but on the printed tablet, as the distinctive title of the $222 \mathrm{nd}$ group. The following is a copy of the tablet pertaining to the 222nd group.

"Genus Ornithoptera and allies.

Bird-zinged Butterflies.

Estimated number of species, 20.

"The species of Ornithoptera, unrivalled in size and unsur- 
passed in magnificence of outline, deservedly stand at the head of the Butterflies.

"They are natives of New Guinea and the neighbouring islands, where, as it is said, the tropical birds are jealous of their beauty, and injure them by pecking at their wings.

"The inhabitants of Darnley Island capture specimens of O. Poseidon, and, securing them by one end of a long thread, they fasten the other end to their hair, allowing the butterflies to flutter round their heads.

" Observe the contrast between the highly-finished colouring in the Humming-bird Butterflies, Erycinida, and the bold massive style in which the gold is laid on in the forewings of the appropriately named $O$. Crosus.

"The genus Leptocircus, judged by for'm and colour, seems to be out of place in this group; but other characters, considered to be of great importance in the classification of the Lepidoptera, such as the venation of the wings and the structure of the legs, indicate its proper place to be in the family Papilionida.

"The only species of the genus Teinopalpus (observe the long and porrect palpi) inhabits the highest ranges of the Himalayas, especially towards the frontiers of Assam."

Thus far we have noticed the schedule and the tablet.

3rd. Foreign species. The further portion of each drawer, to the extent of three-fifths (more or less) of the whole area accommodates from 10 to 60 exotic species, singly or in pairs, such species as are most distinct being preferred. A reference to the authority accompanies, as a rule, the generic, sub-generic, and specific names. The locality, when copied from a monograph, is stated simply; but when it is known where the specimen has been collected, the word "from" is added, e.g., "Omithoptera Crosus, from the Island of Batchian." 
4th. British species. The nearer right-hand corner of each drawer is occupied by representatives of the group indigenous to Britain. Some groups have no British representatives; in others, e.g., Noctua genuina, a selection from the British species fills three-fourths of the drawer. Amongst these, foreign specimens of rarities are admitted; but in all such cases the words "exotic specimen" are appended to the name on the label.

5th. Earliest fossils. The nearer left-hand corner in each drawer is assigned to a few fossils, showing the earliest appearance of the group in the geological series. In some instances, e.g., Hippurites, Rugosa, and the Trilobites, the entire group is represented only by fossils ; in other's, fossils are absent.

6th. The printed tablet. Between these two latter sections of each drawer is placed the printed tablet, about the size of an octavo page. It exhibits an attempt to describe some of the salient points in the life-history of the group. Here, and throughout the series, some attention has been given to ensure legibility by the use of moderately large type, names and descriptions being of much less value when they cannot be read easily.

7th. Diagrams and other illustrations. The upright portion of the table-case over each drawer is given to miscellaneous illustrations of the group. The series includes drawings, plates, and photographs of structure and anatomy, economic products, silk in various stages, marine and fresh-water pearls, cameos, from the rough medallion cut from the shell to the finished work, polished shells, and sections showing the interior of shells, eggs and egg-cases, preserved larvæ and pupæ, preparations in spirits, examples of mimicry, nests of Hymenoptera, galls and their tenants; timber and stone pierced by molluses, crustacea, and insects; malformations 
and distorted growths, healed fractures, coral beads, British and exotic specimens of fungi growing on pupæ, and many other objects of interest.

8th. Species and varieties. The blocks on which some of the table eases rest are fitted with drawers suitable for receiving an extended series of species and varieties, valuable only to the student, and intended to be seen only on application to the Curator. Very little progress has hitherto been made in carrying out this portion of the plan, which has, however, the good effect of rendering it quite needless to overcrowd the groups with less significant species.

The difficulties attending the formation of the series have not been very great. Collections have been presented to the Museum by several friends of natural science, amongst whom may be mentioned $\mathrm{Mr}$. Sarrel Surth, of Liverpool, the donor of a collection of shells rich in generic forms and in costly varieties of the highest beauty. Mr. Moore has been successful in establishing friendly communications with many captains of merchant vessels sailing from the port of Liverpool, some of whom have been supplied by the Committee of the Museum with dredges and collecting apparatus, and have become enthusiastic naturalists. In recognition of their services, several of them have been received as Associate Members of the Literary and Philosophical Society of Liverpool, a distinction which seems to be highly appreciated by them. Something has also been done in the way of exchanges; but a large proportion of the whole series has been selected and purchased specimen by specimen. No object has been purchased simply on account of its rarity; but at the same time no reasonable expense has been spared in procuring the most beautiful and perfect examples.

A few general remarks on the subject of expense may be permitted; details will gladly be communicated to enquirers 
connected with museums. It is notorious that few collections exhibited to the public will bear comparison with corresponding series contained in private cabinets. Why should this be any longer permitted? It may arise in part from the impression that in public museums it is unnecessary to spend much on specimens. Public collections depending chiefly on donations are however likely to be overstocked in some departments, whilst entirely deficient in others. There can be no excuse for extravagance, but a rigid economy may be pushed too far. The trouble and great risk of collecting in tropical climates must often be very inadequately represented by the apparently high prices asked for the chief desiderata, and the rest of a collector's stock may remain on his hands for years.

Again, if a genus or a group is illustrated in nature by a great number of distinct and beautiful forms, $e . g$. , such genera as Madrepora, Conus, Cetonia, \&c., this surely is of itself a biological fact which may claim, even on scientific grounds, to be fairly and appropriately represented in a collection. Even on the most severe estimate of what is necessary for an. educational series, something must be allowed simply for the sake of beauty and attractiveness; that is to say, if museums are to avoid the fate of certain parochial lending libraries which contain only such books as, it is said, everybody ought to like to read.

Why moreover should the public be encouraged to esteem art treasures as so much more valuable than the choicest productions of nature? One hears of a pair of vases being sold for two thousand pounds, a sum which would provide twenty first-rate table cases, and stock them with very fair illustrations of the whole of the invertebrate groups. It is a happy circumstance that a museum of common objects may at a trifling cost be established in almost any village, and, with 
xiv.

judicious local influence brought to bear upon it, may prove both useful and creditable; but why should not wealthy communities, possessing endless drawing-rooms ablaze with costly decorations, exercise something of a corresponding liberality towards the museum of natural history, which is the representative of their appreciation of that which is higher than the highest art?

Considerable difficulty has been found in selecting appropriate materials for the printed tablets. Many of the chief continental authorities on invertebrate animals, admirable as are their works for the purpose of identifying species, afford scarcely a line of information on the life history of the objects they so grandly figure, and often so elaborately describe. Even the reports of scientific expeditions may frequently be searched in vain for this kind of information, which has to be gleaned from authorities not always trustworthy, from scattered papers, or from a few books of travel such as those which have been issued in this country on the Malay Archipelago and the River Amazon, and more recently on Nicaragua.

It is mortifying to have to exhibit forms distinguished by extraordinary developments of structure, and to be able to say nothing on associated habits. Such strange developments were once considered to be mere freaks of nature, but no one now doubts their having a biological and even a genealogical significance. What a field is here opened! How little of the biology of a new form has been exhausted when it has been collected, named, described, figured, and even dissected. Scientific treatises have prepared the foundation for a solid knowledge of the subject; but there would be occasion for regret if biology should ever come to be regarded by students in an aspect too exclusively morphological, histological, or even physiological, if such a view operated to the disparagement of genuine out-of-door observations. The greatest 
advance in Natural History made in the present, or perhaps in any generation, has been mainly accomplished by two observers, who are pre-eminently life-historians and out-ofdoor naturalists.

Little need be said of the miscellaneous illustrations contained in the upright portions of the table cases. They seem to be very successful in engaging the attention of visitors of all classes-a point which is felt to be of prominent importance where the admissions amount, taking the average of open days throughout the year, to about 2,000 daily. What brings them here? is a question which again and again suggests itself. Reduce the number by all the idlers and mere sight-seers who, no doubt, constitute a large proportion of the gathering; still, if only 100 or even 50 per day seek some kind of instruction, even these in the course of a year form a large and teachable class. As a firm believer in the humanising effect of an intelligent interest in Natural Science, to myself the grand museum problem seems to be, how to make such an institution most beneficial to the greatest number.

In estimating the value to the public of a Museum of Natural History, the speciality of its function should not be overlooked. It occupies a position quite peculiar to itself, and does, or claims to-do, what in its absence must be left undone. Many may desire to look upon the wondrous forms which constitute the population of the sea, the lake, the river, the forest, or the grassy plain, but it is only in very rare instances that such far off dwelling places can be explored by those whose lot is cast in the busy centres of social life. The Museum is the best, if not the only, resource.

It is not thus in the departments of Natural Philosophy and Art. Chemistry, Mechanics, and other allied branches of knowledge, lead so directly to practical advantages, that in almost every large town opportunities of many kinds and 
in various quarters are afforded for the study of such obviously useful sciences. Art, including music, has its representative centres in thousands of homes; and, omitting other and more select illustrations, I will venture to affirm that the cultivation of a taste for much that is refined and beautiful in art has very effective aid in the collections displayed to meet the eyes of all who pass through the streets of a populous town. It is probable that such exhibitions are not made with purely educational intentions; but as commerce is the great promulgator of civilisation, howbeit not always undertaken for that purpose, so trade, in its free display of choice fabrics, mechanism, jewelry, ceramic wares, engravings, and sometimes even pictures, is a benefactor to the public taste.

I own myself indebted for many pleasant hours to the shop-windows, pleasant, but not exempt from the recurrence of the question, Are there not other examples of embroidered tissues, of exquisite machinery, of purely combined colours, and graceful configurations, unseen by the throng, and yet as suitable as these to gratify the beholder's? And it has been consolatory to remernber that there was, not far away, one place at least where some care had been taken to invite attention to the rares of Nature's own handiwork.

I am disposed to set a high value on the delight afforded simply by the beanty of natural objects. A specimen without a history, or even without a name, that calls forth a genuine exclamation, How beautiful! fulfils a noble mission; especially when the observer is a child, or young.

But the aim of a museum is to do something more than this. No mere assemblage of rare and beautiful objects can impart more than a small portion of the gratification capable of being conveyed by a store of natural productions. It is the exhibition of the order and affinity between one form and another, and between successive groups of forms, that constitutes the chief function of a museum. 
In reporting the progress of a work which has found employment for me more or less constantly during a period of twelve or thirteen years, it is a gratifying duty to acknowledge the assistance afforded me from many quarters. An impulse highly favourable to the success of the plan was given at the outset, by the provision of a series of Table Cases such as I have not seen surpassed elsewhere. This has been seconded by the purchase from time to time of many valuable works on biology, chiefly Continental, and such as are rarely to be found in provincial libraries, though almost indispensable for the study of special classes of the Invertebrata. Liberal consideration has moreover always been given to the acquisition, by purchase or otherwise, of specimens necessary for the Collection. Acknowledgments are also due to the Chairman and Members of the Museum Committee, not only for the honour of a place at their board, but also for the sympathy and support which liave rendered the meetings of the Committee occasions to myself of much gratification.

To Mr. Moone, the Curator of the Museum, I am indebted for many valuable suggestions, especially for the very important recommendation through which the series has been made an ascending instead of a descending one. The Echinodermata chiefly, and the Crustacea almost entirely, were obtained for the Museum through Mr. Moort. Nearly the whole of Echinoidea were named by Professor Alexander Agassiz, on one of his visits to the Museum ; and it was only in the course of naming and arranging the rest of the Echinodermatc and the Crustacea that the care and discrimination shown by $\mathrm{Mr}$. Moore in the selection of the specimens became fully known to me. One very valuable class of acquisitions, those collected and presented by Masters of merchant vessels, may justly be in a great measure attributed to the interest and good will enlisted in favour of the Museum by the unfailing courtesy of the Curator. 
In completing the eighty-four groups assigned to the Mollusca, I have been much indebted to the assistance of $\mathrm{Mr}$. Frederick Price Marrat, a long known and highly esteemed friend, whose intimate and very extensive acquaintance with shells, as also with the perplexing synonyms of conchology, has rendered his services of the highest value. The identification and manipulation of the specimens, within the groups, in the Mollusca, and also in the Colenterata, has for some time past been almost entirely entrusted to him. In the manipulation of the Crustacea and Echinodermata, I have been fortunate in having the efficient aid of $\mathrm{Mr}$. JoHN CHARD, whose coloured drawings appear with excellent effect in most of the twenty Table Cases.

The following Synopsis is designed to shew the systematic position and limits of each group. The arrangement in the higher divisions, sub-kingdoms, provinces, and classes, is almost entirely in accordance with the classification adopted by Professor Huxuey, and published in The Student's Manual of Geology, by J. Beete Jukes, M. A., F.R.S., 1872. The derivations of many scientific names have been given in Greek characters, to avoid the ambiguity inseparable from the use of English letters to express Greek words.

The Tablets in each group, as a rule, do not refer to the particular specimens exhibited; but in the Synopsis some objects of more than ordinary interest are often specified. Visitors inspecting the Collection have frequently expressed themselves gratified by having their attention called to illustrations which might otherwise have escaped their notice. To most of the groups have therefore been appended short notes, designed to render the Synopsis in this respect useful as a handbook to the Collection. 
Frontispiece. To admit as much light, and to obstruct the view of the specimens as little as possible, the upper wooden frames of the table cases are reduced to the narrowest limits consistent with firmness and security. In the upright compartment the top, bottom, and ends, as well as the sides, are of plate glass, and if a shelf is required it is made of the same material. To give readier access to the specimens, both sides of the upper compartment fall. To exclude the dust, piano-forte hinges are used; each frame closes on double strips of velvet; zinc gutters underlie every crevice; and in addition to the locks, bolt-screws are used, which by a half-turn bind the frames closely down in every part.

As text-books for students of Zoology, the following works may confidently be recommended: A Manual of Zoology, by Henry Alueyne Nicholson, M.D.; and Introduction to the Study of Biology, by the same Author. Published by W. Blackwood and Sons. 
TABLE OF THE ARRANGEMENT ILLUSTRATED IN THE FOLLOWING SYNOPSIS.

Sub-kingdom PROTOZOA.

Classes MONERA, GREGARINIDA, RHIZOPODA, SPONGIDA, INFUSORIA.

Sub-kingdom CELENTERATA.

Classes HYDROZOA, ACTINOZOA.

Sub-kingdom MOLLUSCA.

Classes POLYZOA, TUNICATA, BRACHIOPODA, LAMELLIBRANCHIATA, PTEROPODA, GASTEROPODA, CEPHALOPODA.

Sub-kingdom ANNULOIDA.

Classes ECHINODERMATA, SCOLECIDA.

Sub-kingdom ANNULOSA.

Classes ANNELIDA, CRUSTACEA, MYRIAPODA, ARACHNIDA, INSECTA. 


\section{S Y N O P S I S}

OF AN ARRANGEMENT OF

\section{INVERTEBRATE ANIMALS.}

firist Table Case.

The Mark indicates specimens or other illustrations exhibited in the Cases.

\section{Sub-kingdom PROTOZOA.}

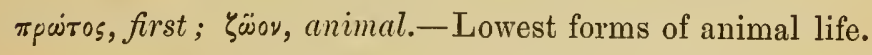

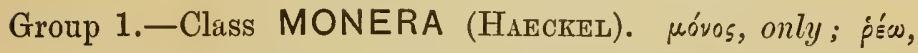
I flow. Living gelatinous matter extending over vast areas of the ocean bed at great depths.

T Drawing of Bathybius haeckelii, Huxuex, enclosing coccoliths.

Class GREGARINIDA (Leon Dufour), gregarius, occurring in numbers together. Found chiefly in the intestines of insects and worms.

I Drawings illustrating reproductive phenomena in Gregarina. Section exhibiting Eozoon.

Many minute aquatic organisms of very simple structure, but of active habiss, are here left unnoticed, as belonging probably to the Vegetable Kingdom, or as of uncertain development. 
Class RHIZOPODA (Dujardin). $\dot{p}(\zeta)$, root; noùs, foot.-Limbs formed by simple extensions of the soft body.

Order FORAMINIFERA. Foramen, an orifice; fero, I carry. Animalcules forming calcareous, rarely arenaceous, shells, found in sponges, sand, etc. The Foraminifera are exclusively marine, and have a worldwide distribution.

Group 2.-FORAMINIFERA-IMPERFORATA and allies.

IT Models, by D'Orbigny and Fric', of about fortysix species. Cycloclypeus, specimen $1 \frac{3}{4}$ inches in diameter, collected and presented by Dr. Collingwood.

Upper Compartment.

Drawings of Amoba and Actinophrys sol.

Group 3.-FORAMINIFERA-PERFORATA.

I Models, by D'Orbigny and Fric, of about seventysix species, including Globigerina and other Rhizopoda, from the deep seas.

Group 4.-Order RADIOLARIA. Radius, a ray. Marine animalcules, constructing exquisitely formed glassy shells.

T Photographic plates of Polycistina, from Barbadoes. 
Class SPONGIDA. $\sigma \pi o_{\gamma \gamma} \circ$, a Sponge.

Till very recently this class has been much neglected. A fine old work by Esper, 4 vols., 4to, contains many plates of Sponges; but these have been superseded by the investigations of Haeckel, Schmidt, Gray, Bowerbank, Carter, and Saville Kent. The groups exhibit a small portion only of the entire collection, which Mr. T. Higgin, of Huyton, has kindly undertaken to name and arrange for the use of students.

Group 5.-Orders MYXOSPONGIÆ and CALCISPONGIÆ (Hacckel). Calcareous Sponges, and Sponges possessing no fibrous endo-skeleton. Estimated number of species in class Spongida: British, 200. Bowerbank, 1864-66.

Order FIBROSPONGIE (HAECKEL).

Group 6.-Family HEXACTINELLIDÆ (SchmidT), Part I. £乡, six: áxтiv, a ray. Spicules silicious, with rectangular rays.

Genus HYALONEMA. i $\alpha \lambda \circ$, crystal ; $\nu \tilde{n} \mu \alpha$, thread.

T Hyalonema Sieboldii, the glass-rope Spongeseveral specimens, exhibiting the body of the sponge attached to the stem encrusted by the commensal zoophyte, Palythoa.

Genus EUPLECTELLA. हư well; $\pi \lambda \varepsilon x \tau$ s, twined.

Euplectella aspergillum. Sponge from the Island of Cebu, Philippines, where it is known by the name of "Regadera." It has also been called Venus's Flower-basket.

Meyerina claviformis (GRAY). A very rare and beautiful sponge, from the same locality with the preceding; length 26 inches, greatest diameter $3 \frac{1}{2}$ inches. The body of the sponge is seen enclosed in a sheath resembling the finest lace-work. Imported and presented by Capt. Snook, ship T. E. Lemon. 
Group 7.-Family HEXACTINELLIDÆ (Schмidt). PartII.

T Pheronema Grayi (Kent).

Collected off the coast of Portugal, and presented by W. Saville Kent.

Holtenia Carpenteri (Wyville Thomson).

Globular Anchor-Sponge, collected during the expedition of H.M. S. "Porcupine," and presented by Prof. Wrville Thonson. Specimens of allied fossils, Ventriculites and Choanites, from the chalk formation.

Group 8.-Remainder of Order FIBROSPONGIÆ (HAECKEL).

I Series of British Marine Sponges; specimens of fresh-water sponge, Spongilla, collected at Rainhill, and presented by Charles Longuet Higgins.

Upper Compartment.

Specimens exhibiting many of the remarkable varieties of form assumed by the Pibrous Sponges.

Group 9.-Class INFUSORIA = STOMATODE PROTO$\mathrm{ZOA}$.

The class thus restricted includes a small section only of the INFUSORIA of the older authors.

Tा Coloured Drawings of Stentor, Vorticella, Noctiluca, \&c., chiefly from Ehrenburg, Die Infusionsthierchen als Volkommene Organismen. Leipzig, 1854-6. 


\title{
Sub-kingdom COFLENTERATA.
}

\author{
(Frei \& LeUckart.)
}

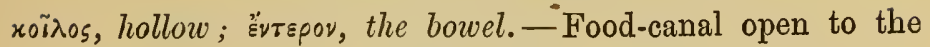
body-cavity.

Class HYDROZOA (HUXLEY). Internal cavity simple.

A monograph of the Hydrozoa is much needed. Ellis and Solander, 4to, and Lamouroux, Histoire des Polypiers Flexibles, describe comparatively few of the species now known to science. Recent works on the subject, such as "Contributions to the Natural History of the United States, by L. Agassiz," are chiefly confined to local productions.

Sub-class HYDROIDA; animals resembling the Hydra. Group 10.-Order HYDRIDA-GYMNOCHROA (Hincks). rupvòs, naked; xpóx, the skin. Estimated number of species : British, 4.

I Drawings of several species of Hydra, and of the modes of its reproduction by buds and ova.

Group 11.-Order HYDRIDA-THECAPHORA (Hincks).

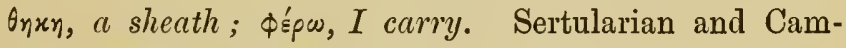
panularian Zoophytes. Estimated number of species: British, 92. Hincks.

T Series of British Zoophytes, collected and presented by H. H. H. Small series of Exotic Zoophytes. Examples of Graptolites.

Upper Compartment.

Drawings of ovarian vesicles of Sertularia.

Group 12.-Order HYDRIDA-ATHECATA (HINCKS). a without; $\theta_{\eta \times \eta}$, a sheath. Tubularian Zoophytes. Estimated number of species: British, 70.

It Specimens of the horny tubes of Tubularia, and of Eudendrium.

Upper Compartment.

Drawings of medusiform gonophores, \&c., illustrating reproductive phenomena in Coryne. 


\section{Second Table Case.}

The mark indicates illustrations exhibited in the cases. The colouned drawings are by JoHn CHand, Liv. Pub. Mus.

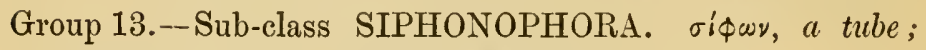
фépos, I carry. Oceanic Hydrozoa.

T Specimens and Drawings of Porpita, Velella, and of Physalia, the "Portuguese Man-of-War."

Upper Compartment.

Preparations in liquid of the animals of various HydrozoA.

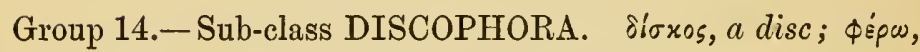
I carry. Naked-eyed, or True Meduse.

T Coloured drawings of these very beautiful, but small and little-known, Jelly-fish.

Group 15.-Sub-class LUCERNARIDA. Lucerna, a lamp. Hidden-eyed Medusz.

T Drawings of the Hydra-TUBA, and its development: and of various ACALEPHe, including the common Jelly-fish of our shores, which are in fact the free-swimming flowers, gonophores, of the little stationary Hydra-tuba.

Group 16.-Sub-class MILLEPORIDA. The animals are propagated by free-swimming Medusiform Gonophores.

T Specimens of the Coralla of various Millepores from the West Indies, where they are familiarly known as " Sea-ginger."

Upper Compartment.

Drawings of the animal of Millepora. 


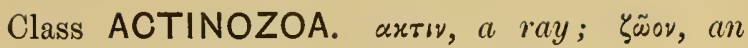
animal. Internal cavity compound.

The groups in this class are named and arranged chiefly after. Milne Edwards' Histoire Naturelle des Coralliaires; but most valuable aid has been received from the magnificent work by James Dana, on the Zoophytes of the United States Exploring Expedition, 1838-1842.

Group 17.--Order RUGOSA. rugosus, wrinkled.

The members of this order are, with rare exceptions, only known as Palæozoic fossils. The rays are in multiples of four.

I) Polished sections, chiefly from Devonian rocks. The Order Rugosa includes 224 species.

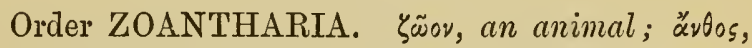
a flower. Parts in multiples of 5 or 6 .

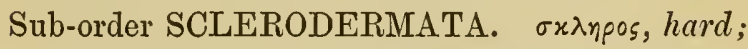
Sépuc, the skin. Corallum secreted within the animal.

Division TABULATA. Corallite divided by horizontal plates : rays not developed.

Group 18. - Genera SERIATOPORA (LAMARCK), and POCILLOPORA (Blainville). The former from series, a row; the latter from pocillum, a little cup. Estimated number of species : recent, 28 ; British, 0 ; fossil, 14 ; Palæozoic.

T Corals from the Pacific and Indian Oceans, including a very beautiful Seriatopora possibly undescribed: other examples from the Red Sea, \&c.

Group 19.-Family FAVOSITID王. Favus, a honeycomb. Estimated number of species, 102 ; all Palæozoic fossils. I The Chained-Coral and other species from the Wenlock Limestone, \&c. 
Division PERFORATA. Rays well developed: coral porous.

Group 20.-Family PORITIDÆ. Reef-building corals, usually massive. Estimated number of species : recent, 83 ; British, 0 ; fossil, 36.

T Examples of Psammocora, Montipora, Alveopora, and other genera.

Group 21.-Sub-family TURBINARINÆE (MILNE EDWARDS). Turbo, a top.

Genus TURBINARIA (OKEN) = GEMMIPORA (BLAINvilLe). Estimated number of species: recent, 11 ; British, 0 ; fossil, 7.

T Large foliaceous and cup-shaped Corals from the East Indies and the Fiji Islands. Domeshaped specimen of Astrcoopora, remarkable for its highly finished calices.

Group 22.-Genus MADREPORA (Linnæus). Part I. The name is from the Italian, signifying Mother-pore, the apical polype being the parent of the rest on the same branchlet. Natives of tropical seas: one species is known from the White Sea.

Upper Compartment.

Larger Corals, including $M$. palmata, an explanate Madrepore, sometimes attaining a height and breadth of seven feet.

Group 23.-Genus MADREPORA (Linneus). Part II. Estimated number of species in genus Madrepora; recent, 84 ; British, 0 ; fossil, 6 ; Kainozoic.

T $M$. echinata, $M$. carduus, $M$. longicyathus, and other slenderly branched Madrepores, are amongst the most beautiful of all the coral tribe. 
Group 24.-Genus DENDROPHYLLIA (BlaInvilLe) and

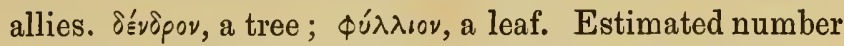
of species : recent, 28 ; British, 0 ; fossil, 31 ; Kainozoic.

The Corals of this group grow in waters of all temperatures.

T $D$. nigrescens from Singapore, and $D$. ramea from the Mediterranean : the latter attains a height of five feet, and possesses an agreeable fragrance.

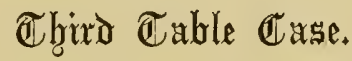

The Mark I indicates specimens or other illustrations exhibited in the Cases.

Division APOROSA. Coral compact in substance.

Family FUNGIDæ. Coralla chiefly explanate; polypo centres not circumscribed.

Group 25.-Genus AGARICIA (LAMARck) and allies. 'ayapıxos, a mushroom. Estimated number of species: recent, 17 ; British, 0 ; fossil, 13 ; chiefly Kainozoic.

I Species from the West Indies and the Pacific. A. undata grows on the vertical sides of rocks, like a large flower with the corolla fully expanded, and beautifully ripple-marked.

Group 26.-Genus LOPHOSERIS (MILne Edwards) and

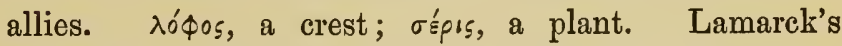
name for this genus, Pavonia, alludes to the expanded disc of the coral, with polype-mouths in place of the eye-spots of the Peacock's tail. Estimated number of species: recent, 24 ; British, 0 ; fossil, 42.

IT Examples from the Indian and Pacific Oceans. Upper Compartment.

L. pratorta, curiously intricate in its growth. 
Group 27. - Genus FUNGIA (Lamarck) and allies. Estimated number of species: recent, 32 ; Britisk, 0 ; fossil, 9 ; chiefly Mesozoic.

T Specimens of Fungia, shewing the attachment of the young corals to the under-side of the parent coral, which is itself free and unattached.

Specimens of Herpetolitha, the Slug-coral; and of Polyphyllia, the Mole-coral.

\section{Upper Compartment.}

Genus Halomitra Dana; the corallum is deeply cup-shaped, and shews, within, the truncated frustrum of a former corallum on which the present specimen seems to have been developed. The same peculiarity has been observed by the writer in other specimens of Halomitra.

Group 28.-Genus MERULINA (Ehrenberg). unpúw, to wind, in allusion to the corded appearance of the surface. The coralla take the form of leaves spread out one above the other. Estimated number of species: recent, 7 ; British, 0 ; fossil, 0.

I Specimens from the Sooloo Sea and the Fiji Islands.

Group 29.-Genus ECHINOPORA (LAMARCK). Echinus, the Hedge-hog. This and the preceding group exhibit forms of transition between the Fungidæe and the Astræidæ. Estimated number of species : recent, 8; British, 0 ; fossil, 1.

IT Specimens from the Indian Ocean and the Red Sea. 


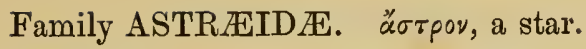

Group 30.-Division ASTRÆACEÆ (MILNE EdwARDs) and allies. The species of this group are amongst the most important of reef-building corals. Estimated number of species: recent, 122; 'British, 0; fossil, 267. Mesozoic and Kainozoic.

T Heliastrca, Acanthastræa, Astræa, Prionastrca, Isastrea, Culicia, \&c.

\section{Group 31.-Section LITHOPHYLLIACE 2 MEANDRO.} İD环 (MILnE EdWARDs). Estimated number of species: recent, 69 ; British, 0; fossil, 34 ; chiefly Kainozoic.

बा Brain Corals. The polype-cells form long sinuous channels like the windings of a stream, or the convolutions of the brain; hence the familiar name.

In the Lettuce Coral, the cell-walls are as thin as paper, the polypes large and beautifully coloured.

Upper Compartment.

Meandrina mammosa, called by sailors Neptune's Shield; and other large corals.

Group 32.-Sections LITHOPHYLLIACEÆ CESPITOSÆ et SIMPLICES (Milne Edwards). Estimated number of species: recent, 30 ; British, 0 ; fossil, 154. From the Trias upwards. In genus Mussa (OKEN), as in Astrea and Meandrina, the corals grow in hemispheres attaining ten or twelve feet in diameter, adorning the ocean bed with richly coloured cupolas.

T Examples of nearly all the recent genera. 
Group 33.-Sub-Family EUSMILINÆ (MrLne Edwards)

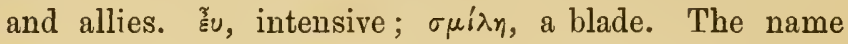
alludes to the well shaped and prominent blades which form the rays of the calices. Estimated number of species: recent, 54; British, 0; fossil, 248. Mesozoic and Kainozoic.

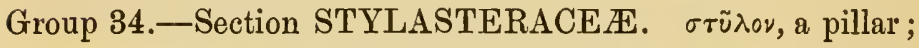

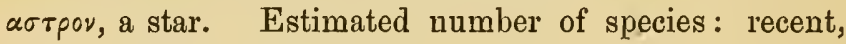
13 ; British, 0 ; fossil, 0.

T Corals small in size, but of rare beauty in colour, and peculiar in their form, which somewhat resembles that of espalier trees. From Australia and the Pacific.

Group 35.-Genus OCULINA (Lamarck) and allies. Estimated number of species: recent, 18 ; British, 0 ; fossil, 18. Chiefly Kainozoic.

T The group includes the White-Coral of the Mediterranean, and some very interesting species from Northern Seas.

Group 36. - Family TURBINOLID $\approx$ and allies. 'Turbo, a top. Solitary corals, more abundant in former periods than at present. Many of the existing species were unknown before the comparatively recent use of the dredge in deep waters for scientific purposes. Estimated number of species : recent, 47 ; British, 3 ; fossil, 134. Mesozoic and Kainozoic.

T Turbinolia, British; presented by R. McAndrew; Caryophyllia, Flabellum, Sphenotrochus, \&c.

Glass models of the polypes in their proper colours. 


\section{frourth Table Case.}

The Mark $\uparrow$ indicates specimens or other illustrations exhibited in the Cases. Group 37.--Sub-order ZOANTHARIA-SCLEROBASICA.

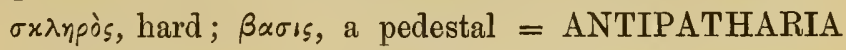

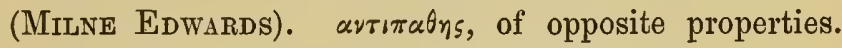
The horny axis of the coral is thickly beset with short spines, and is covered by the common tissue uniting the polypes. Estimated number of species: recent, 24; British 0 ; fossil, 1.

T Specimens of Antipathes and Cirrhipathes, the former shrub-like and delicately branched; the latter with a simple stem growing in a loose coil. The species are widely distributed, growing on rocks in deep water.

\section{Upper Compartment.}

Antipathes arborea, the black coral of commerce; rough, and manufactured into beads.

Group 38.-Sub-order ZOANTHARIA - MALACODERMATA. $\mu \alpha \lambda \alpha \times \circ \varsigma$, soft; $\delta s ́ p \mu \alpha$, the skin $=$ ACTINARIA (Milne Edwards). áxтiv, a ray. Distinguished by the absence of a solid corallum. Estimated number of species : recent, 200 ; British ; fossil, 0.

Tा Models in coloured glass of about 30 species of British Sea Anemonies.

Order ALCYONARIA. $\dot{\alpha} \lambda x v \dot{\alpha} v$, the Halcyon of the ancients. In this order the polypes have eight fringed tentacles.

Group 39.-Family PENNATULIDÆ. Penna, a feather. The quill of the Sea-Pen during the life of the animal remains plunged into the mud at the bottom of the sea, but does not contract any adherence. Estimated number of species : recent, 26 ; British, 3 ; fossil, 1.

T Examples of Pennatula, Virgularia, Pavonaria, Renilla, \&c.

$$
\text { Upper Compartment. }
$$

Quill of a gigantic Sea-Pen, from British Columbia. 
Family GORGONIDÆ. ropyì, the Gorgon of the ancients.

Group 40.-Genus CORALLIUM (LAMarck). xóp daughter; $\dot{\lambda} \boldsymbol{\lambda} \circ$ s, of the sea. Estimated number of species : recent, 3 ; British, 0 ; fossil, 2 ; Kainozoic.

T Specimens of Corallium rubrum, the Red Coral of the Mediterranean; one very large, with more than 40 tines.

Group 41.-Sub-family ISIDIN (MILnE EdwaRds). I $\sigma \triangleleft \sigma$, the goddess Isis. Estimated number of species: recent, 13 ; British, 0 ; fossil, 4 ; Kainozoic.

T Mopsea, with slenderly forked branches; Isis, (decorticated) with black and white articulations, and Melitea with various shades of scarlet and bright yellow: all have joints or rendering them more or less flexible.

Group 42.-Sections GORGONELLACE E and BRIARACÆ (Milne Edwards).

Section is here used as equivalent to 'Agèle' (Milne EDtards).

Estimated number of species: recent, 15; British, 0 ; fossil, 0 . The axis of the stem is either sub-calcareous, or made up of spiculæ.

T Examples of Verucella and Juncella, and a very beuutiful specimen of Paragorgia Johnsoni from Madeira, presented by its discoverer, J. YATE JoHNSON.

Group 43.--Section GORGONACEÆ. Part I. Foliaceous.

Estimated number of species : recent, 25 ; British, 2.

I Phyllogorgia, in which the polype crust is expanded, forming wings on each side of the stem. Rhipidigorgia, or Sea-Fans, in which the branches repeatedly unite, forming a network. 
Group 44.-Section GORGONACE E. Part II. Arborescent. Estimated number of species: recent, 58 ; British, 2. The base of the Gorgonia polype secretes the tough horny elastic stem : another portion of the same polype secretes the soft crust, or bark, which owes its beautiful colour to the presence of calcareous spiculæ.

I Examples of most of the genera; but the larger fruticose forms occupy the upper compartment.

Group 45.-Section PRIMNOACEÆ. $\pi$ ér $\mu \nu \alpha$, the poop of a ship. On the coast of Norway Primnoa is said to attain the height of fifty or sixty feet. Estimated number of species: recent, 13 ; British, 1.

T Primnoa verticillata from Madeira, presented by J. S. Tyerman. Primnoa lepadifera is a desideratum.

Family ALCYONIDÆ. No solid central axis.

Group 46.-Sub-family TUBIPORINÆ (MILne Edwards).

Estimated number of species: recent, 7 ; British, 0 ; fossil,

T Specimens of Tubipora musica, the Organ-pipe coral, and of other species of the genus, from the Indian and Pacific Oceans and the Red Sea.

Group 47.-Sub-family ALCYONINÆ (Mrlne Edwards) and allies. Estimated number of species: recent, 50 ; British, 3 ; Fossil, 0.

T Examples of Spoggodia, and other genera. Coloured drawings of Alcyonium digitatum, with the polypes expanded, and of other species, chiefly after Dana. 
Group 48.-Order CTENOPHORA. xтвіs, a comb; $ф \varepsilon p o$, I carry. Transparent oceanic Actinozon, resembling in habit some of the smaller Jelly-fish, but much more highly organized. Swimming by means of cilia arranged in vertical comb-like rows.

ণ Coloured drawings of Pleurobrachia = Cydippe, Cestum, Idya, \&c., chiefly after Buainvilue, Lesson, and L. Agassiz.

\section{diffth $\mathbb{C a b l e} \mathfrak{C}$ ase.}

The Mark I indicates illustrations exhibited in the cases. The coloured drawings are by $\mathrm{J}_{\mathrm{OHN}}$ CHaRd, Liv. Pub. Mus.

\section{Sub-kingdom MOLLUSCA.}

mollis, soft.

Province MOLLUSCOIDA. Ab-normal MOLLUSCA.

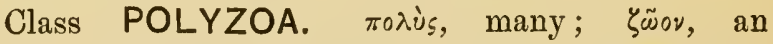
animal. Estimated number of species: recent, 360, (Busk, 1854) ; British, 112, (Johnston, 1847); fossil, 1,600 ; from the Silurian upwards.

A monograph of the class PoLYzos, combining the fossil with the recent species, after the admirable method of MiLne Edwards in his Histoire Naturelle des Coralliaires, may be regarded as an achievement worthy of the ambition of any Naturalist. Taking into consideration the exquisite beauty of the species, their wide distribution in time and space, their convenient size, and the interesting questions connected with their structure and habits, no other unoccupied Biological field seems to present equal attraction.

The three groups here assigned to this class are based upon characters by no means satisfactory, but it has been found convenient to retain them. The more scientific distinctions are illustrated by coloured drawings in the upper compartment. 
Group 49.-Genus RETEPORA (LaMARCK); rete, a net; and allies. Polyzoarium chiefly calcareous and rigid.

T Examples of Tubulipora, Cellepora, Idmonea, Hornera, \&c., including some very beautiful Retepores and other Polyzoa from the Atlantic Cable. Oldhamia from the Cambrian rocks, possibly a plant.

Group 50.-Genus FLUSTRA (Linneus). Saxon Flustrian, to weave; and allies. Polyzoarium chiefly horny, foliaceous or explanate.

IT Examples of Lepralia, Carbasea, Membranipora, Electra, \&c. Observe how closely Amathia spiralis (Layrouroux), from Australia resembles in form Archimedipora Archimedea (Lesuer); a fossil from the Carboniferous Limestone, Kentucky. A delicate cup-shaped Flustra on Catenicella.

Group 51.-Genus CATENICELLA (BLAINvilLE); catena, a chain; and allies. Polyzoarium chiefly articulated and flexible.

Tt Examples of Cellularia, Salicornaria, Bicellaria, Emma, Buguta, \&ec.

Upper Compartment.

Diagram of a Polyzoon, and of an "avicularium," or Bird's-head process. Coloured drawings of fresh-water Polyzoa, after AlLman.

The animals of the PoLYzoA are always minute, and live associated in colonies. They are much in advance of the Cerlenterata in complexity of structure; the food canal being entirely shut off from the body-cavity, and the nervous system being well defined. 
Group 52.-Class TUNICATA. Tunica, a cloak. The Ascidians, or Tunicaries, are marine animals, having their internal organs protected by a double integument, tough and elastic, in place of a shell. Estimated number of species : recent, 150; British, 73.

T Coloured drawings of solitary, social, and compound Ascidians.

\section{Upper Compartment.}

Preparations in spirits of Salpians in the chained and solitary states; also of Pyrosoma, and many other Ascidians. Diagrams of the early development of an Ascidian, shewing by the presence of a pseudo-notochord its approach to the form of the vertebrate embryo.

Group 53.-Class BRACHIOPODA. Bpáxi noùs, a foot. The Lamp-shells possess a true upper and under valve. Estimated number of species: recent, 100 ; British, 5 ; fossil, 1,000, from the Silurian upwards.

Ti Examples of nearly all the recent, and of a ferw of the fossil genera.

Upper Compartment.

Animals of Lingula, and other Brachiopoda in spirits.

Group 54.-Order RUDISTES (LAMARCK). Estimated number of species: recent, none known at present; fossil, 100, from the Chalk and Hippurite Limestone.

T Examples of Hippurites: Specimens of Radiolites, Caprinella, Caprina, and Caprotina, are desiderata. 


\title{
Province MOLLUSCA.
}

\author{
MOLLUSCA PROPER.
}

The series of MoLLOSCA was commenced by a small but very useful collection, presented in 1859 by the late Miss YATES, of Liverpool. Some of the desiderata were supplied at the same time by H. H. H. ; others from time to time have been acquired by purchase, especially at the sale of the Dennison Collection, in 1863. A very fine collection of choice Shells was in 1868 presented to the MIuseum, by Samoel Sirtir, Esq., Banker, of Liverpool.

The Recent Species have been named and arranged in accordance with "The Genera of Recent Mollusca," by HeNry and ARTHOr AdAMs: from the same prolific suurce has been derived much of the information recorded in the tablets. The excellent "Manual of the Mollusca," by the late $\mathrm{B}$. P. WoODWARD, and the "Manuel de Conchyliologie," by M. СHENO, have been followed in arranging the fossil illustrations. Of the 1390 Generic and Sub-Generic forms recognised in the "Genera of Recent Mollusca," the collection at present contains illustrations of about 1121. The "History of British Mollusca and their Shells," by Edward Forbes and S. HaNLex, has been used in naming and arranging the British representatives in the 78 groups assigned to the Mollusca Proper.

Class .LAMELLIBRANCHIATA. lamina, a plate; $\beta$ pár $\chi^{i} \alpha$, the gills of fish. = CONCHIFERA (LaMarcK). Bivalve Mollusca.

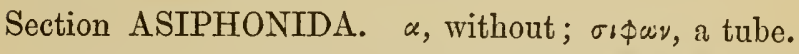

The absence of a respiratory siphon indicates, generally, that the species do not live immersed in sand or mud.

Group 55.-Family OSTREID $\mathbb{E}$ and allies. Oyster. Estimated number of species: recent, 182 ; British, 5; fossil, 200. Carboniferous, \&e.

I Examples of Ostrea, Anomia, Plicatula, Spondylus, Placunanomia.

Upper Compartment.

Placenta orbicularis, used for windows in some parts of China; Group of Pedum in coral of the genus Porites. 
Group 56.-Family PECTENID E and allies. pecten, a comb. Estimated number of species: recent, 220 ; British, 13 ; fossil, 600. Carboniferous, \&c.

T Examples of Pecten, Lima, Radula, Hinnites.

$P$. Proteus, exhibiting contrasts of colour between specimens of the same species. Lima excavata, North Sea. R. M'ANDrew.

Group 57.-Family ARCID王 and allies. arca, a chest. Estimated number of species : recent, 341 ; British, 11 ; fossil, 600. Lower Silurian, \&c. Trigonia, justly admired for the beauty of its pearly interior, and now found only in Australian Seas, is represented by many species in the Mesozoic rocks of Britain.

T Examples of Arca, Trigonia, Nucula, Yoldia, Leda, Cucullea, Pectunculus, Adrana.

Group 58.-Family AVICULID 2 and allies. diminutive of avis, a bird. Estimated number of species: recent, 100 ; British, 2 ; fossil, 450. Silurian, \&c.

I Examples of Pinna, Meleagrina, Avicula, Perna, Creratula.

Upper Compartment.

Large group of Vulsella in sponge.

Group 59.-Family MYTILIDE and allies. Mussels. Estimated number of species : recent, 250 ; British, 12 ; fossil, 220. Silurian, \&c.

T Examples of Atheria, Mulleria, Mytilus, Crenella. Myrina.

Upper Compartment.

Lithophaga in stone. 
Group 60.-Family UNIONIDÆ. unio, a pearl. Rivermussels. Estimated number of species: recent, 574; British, 4 ; fossil, 100 . Tertiary.

T Examples of Unio, Anodonta, Mycetopus.

Upper Compartment.

British Pearls; figures of Bhudda and artificial pearls in Unio plicatus.

Unio multiplicatus; extensive fracture repaired in a very peculiar manner by the animal; from the GASEOIN cabinet.

\section{Siztly Table Cixs.}

The Mark indicates specimens or other illustrations exhibited in the cases.

Section SIPHONIDA. $\sigma \iota \phi \omega \nu$, a tube.

The presence of a well developed respiratory siphon indicutes, generally, that the species live more or less immersed in sand or mud.

Group 61.-Family LUCINID压 and allies. Lucina a name of Juno. Estimated number of species : recent, 362 ; British, 17 ; fossil, 330 . From the Devonian upwards.

If Illustrations of the genera in the families $U n$ gulinida, Laseida, Leptonida, Galeommida, Solemyida, Astartida. Fine series of Crassatella.

Group 62.-Family CHAMID压 and allies. $\chi \alpha \mu \alpha i$, on the ground. Estimated number of species: recent, 52 ; British, 0 ; fossil, 30. From the Chalk upwards.

I Chama, Hippopus, Tridacna, Arcinella, Chametrachaa, acc. Chama Lazarus, very fine. Upper Compartment.

Small example of $T$. gigas, the largest known molluse; the shell attains the weight of $500 \mathrm{Ibs}$. 
Group 63.-Family CARDIID 2 and allies. xapoía, the heart. Cocliles. Estimated number of species : recent, 162 ; British, 9 ; fossil, 300. From the Silurian upwards.

T Cardium, Hemicardia, Bucardia, dcc.

Adacna and Monodachna are generic forms from the Caspian.

Group 64.-Family CYRENID无 and allies. Cyrene, the daughter of a river. The olive-green epidermis indicates a fresh-water habit. Estimated number of species: recent, 255 ; British, 12 ; fossil, 195. Tertiary.

TI Illustrations of the genera in the families Glauconomyida, Cyrenida, Cyrenoidida.

Family VENERID王.

Group 65.--Genus TAPES (MEgERLE) and allies. tapes, tapestry. Estimated number of species : recent, 257 ; British, 8 ; fossil, 60 . Tertiary.

T Dosinia =Artemis, Tapes, Civce, Clementia, Rupellaria, \&c. Sunetta, fine series of species.

Group 66.--Genus VENUS and allies. Estimated number of species : recent, 238 ; British, 6 ; fossil, 160 ; from the Oolite upwards.

I Venus, Callista, Chione, dc.

Chione Kellettii, from the Densison collection.

Family TELLINIDÆ.

Group 67.-Sub-family DONACINE, and allies. Wedgeshells. Estimated number of species: recent, 227 ; British, 10 ; fossil, 60 . Tertiary.

T Donax, Mesodesma, Semele, Ervilia, dc.

Note.-The beautiful interior of Galatea, from African rivers. 
Group 68.-Sub-family TELLININÆE. $\tau$ té $\lambda \lambda \eta$. (Pliny.)

The Tellens, though inferior to the Pectens in striking contrasts of colour, are, in refinement of beauty, at the head of all the bivalve shells. Estimated number of species: recent, 409; British, 20; fossil, 134. Oolite, \&c.

T Tellina, Lucinopsis, Metis, Tellidora, de.

$T$. lata, and others of great beauty.

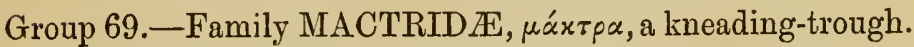

Estimated number of species : recent, 188; British, 8; fossil, 40, chiefly Tertiary.

T Mactra, Lutraria, Harvella, Raëta, Labiosa, dc. Upper Compartment.

Interior of Lutraria, coloured to shew the pallial sinus. Genus Anatinella is a desideratum.

Group 70.-Family ANATINIDE, and allies. anatinus, pertaining to the duck. Estimated number of species: recent, 190 ; British, 17; fossil, 350. Devonian, \&c.

- Thracia, Myochana, Corbula, Periploma, Pandora, \&c. Pholadomya, extremely rare, and a desideratum in a recent state, is a magnificent genus of 150 species as seen in its fossil representatives from the Lias, \&c.

Group 71.-Family SOLENID\# and allies. $\sigma \omega \lambda \dot{\nu} v$, a gutter-tile. Razor-shells. Estimated number of species: recent, 24 ; British, 5 ; fossil,60. Eocene, \&c.

T Mya, Panopaa, Novaculina, de. Saxicava Angasi.

Group 72.-Family PHOLADIDE and others. $\$ \omega \lambda \varepsilon^{\prime} \alpha$, living in holes. Estimated number of species: recent, 131 ; British, 14; fossil, 60 . Eocene, \&c.

T Clavagella, Brechites = Aspergillum, Pholadidea, Parapholas. The true bivalve shell of Asper- 
gillum, not larger than a Laburnum seed, may be seen on the tube.

Upper Compartment.

The tube of Kuphus giganteus. Specimens of wood perforated by Teredo, often called the Shipworm, shewing the destructive character of the borings made by this animal.

\section{Sefrently Cable Case.}

The Mark I indicates specimens or other illustrations exhibited in the Cases.

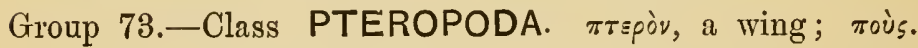
a foot. Pelagic Mollusca, of small size, often found swimming in countless myriads on the surface of the deep, especially on calm evenings, from the tropics to high latitudes. The shells are delicate and glassy. The animals are very simply organised, and resemble the minute but actively locomotive larvæ of the seasnails. Estimated number of species: recent, 73; British seas, 5 ; fossil, several species of Comularia, and other genera, from the Silurian upwards.

T Examples of about 40 species of Balantium, Cavolina Hyalaa, Clio, Limacina, and other genera.

Series containing more than a few species of Pteropoda are rare in collections. For the comparatively numerous examples here exhibited, the collection is indebted chiefly to Captains of merchant vessels sailing from Liverpool, especially to Captains Whiteway, Mortiner and Baker. 


\section{Class GASTEROPODA.}

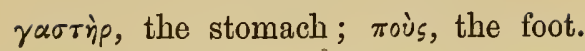

Head distinct, furnished with eyes and tentacles. Body usually protected by a conical or spiral shell. Lower part of the body formed into a thickened, expanded, creeping disc or foot. This class includes all the land and most of the fresh-water and marine univalve Molluscs. The latter when very young have ciliated wings on the sides of the head, by which they swim freely about; the body being contained in a minute spiral shell, having an operculum.-H. \& A. Adars.

Sub-class BRANCHIO-GASTEROPODA, $\beta p^{\alpha} \gamma \chi^{\prec \alpha}$, gills. Organs of respiration constructed to breathe air suspended in water.

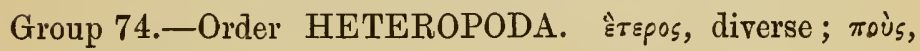
the foot.

This and the succeeding order are retained at the commencement of the Gasteropoda because, although they may be regarded as more highly organized than the Prosobranchiata, they are less characteristic members of the Branchiate Gasteropods.

Estimated number of species : recent, 70 ; British, 3.

T Examples of Oceanic Shells-Janthina, Atlanta, \&c., including Carinaria vitrea.

Upper Compartment.

Coloured drawings of Firola, \&c. Preparations in liquid of Heteropodous animals; Janthina with its raft, from which the eggs of the animal are suspended. 
Order OPISTHOBRANCHIATA. o้ $\pi \sigma \theta \varepsilon$, behind; $\beta p \alpha ́ \gamma \chi \prec \alpha$, gills. Organs of respiration situated towards the rear of the body.

Group 75. - Sub-order NUDIBRANCHIATA. mudus, naked. The Sea-slugs, though destitute of shells, are often highly and beautifully coloured. Estimated number of species : recent, 300 ; British, 26. They are referred to two sections.

Section I.-Aiolobranchiata. aionos, changeable. Gills in parallel rows.

Tा Coloured models of Nudibranchs from the Mersey; Tritonia, Eolis, \&c.

Section II.-Anthobranchiata. ¿゙vos, a flower. Gills in the form of a flower.

Tा Coloured models of Nudibranchs, Doris, \&c.

Upper Compartment.

Coloured drawings and specimens in spirits.

Group 76. - Sub-order TECTIBRANCHIATA. tectus, covered. Gills protected by a shell, or by the mantle. Estimated number of species : recent, 338; British, 23 ; fossil, 100. Trias, \&c.

The animals frequent weedy shores and coral reefs : their bodies often exhibit lively colours, and are frequently much larger than the shells which protect the respiratory organs.

I Examples of most of the genera in the families. Actconida $=$ Tornatcllida, Aplustrida, Cylichnida, Bullide, Philinida, Lophocercida, Aplysiide, Pleurobranchida. 
Order PROSOBRANCHIATA. $\pi \rho \tilde{\omega} \sigma o v$, in front; Bpá $\gamma \chi \prec \alpha$, gills. A very extensive order, comprising most of the univalve Sea-shells best known in collections.

Sub-order SCUTIBRANCHIATA. scutum, a shield. Animals chiefly littoral in their habits, living on rocks or sea-weeds near the shore.

Section EDRIOPHTHALMA. $\approx \delta \rho \alpha$, a seat; $\delta \phi \theta \alpha \lambda \mu \circ \varsigma$, the eye. Eyes sessile. Shell, in the adult, conical, not spiral.

Group 77.-Family CHITONID无. $\quad \chi i \frac{\omega}{\nu}$, a coat of mail. Estimated number of species : recent, 255 ; British, 11 ; fossil, 30, from the Devonian upwards.

T Examples of Lophyrus, Tonicia, Lorica, Cryptoplax $=$ Chitonellus, Mopalia, \&c.

Upper Compartment.

Plates of the shell of Leptochiton, separated to illustrate the homology of the last plate with the entire shell of Patella.

Group 78.-Family PATELLID无 and allies. patella, a dish;

Limpets. Estimated number of species: recent, 142 ;

British, 7 ; fossil, 100 ; from the Silurian upwards.

T Examples of Tectura, Scutellina, Gadinia, Nacella, \&c.

Group 79.-Families FISSURELLIDÆ \& DENTALID压. Duck's-bill Limpets, Key-hole Limpets, Tooth-shells. Estimated number of species : recent, 141 ; British, 7 ; fossil, 144. Devonian, \&c.

The Dentalia have been regarded as Pteropods; also as Fissurella, with highly conical and attenuated shells.

T Examples of Artalis, Scutus = Parmophorus, Emarginula, Cemoria, Lucapina, Tugali, Cranopsis, Macrochisma, \&c. 
Section PODOPHTHALMA. $\pi \nu \dot{\nu} s$, foot; $\dot{\phi} \phi \theta \alpha \mu \nu$, , eye. Eyes on foot-stalks.

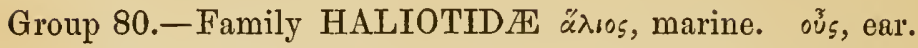
Estimated number of species: recent, 74; British, 1 ; fossil, 4. Miocene.

\section{Upper Compartment.}

T Series of polished Haliotis, including the principal kinds used in the manufacture of papiermaché articles, card cases, \&c.

\section{Family TROCHID无.}

Group 81.-Sub-Family ASTRALIINE and allies. $\alpha \sigma \tau p o v$, a star. Estimated number of species: recent, 200 ; British, 3 ; fossil, 5. Miocene.

T Examples of Stomatella, Gena, Stella, Rotella, Guilfordia, Broderipia, Trochiscus, Camitia, Microtis, Scissurella, \&c., constituting an assemblage of very beautiful generic forms.

Group 82.-Sub-Family TROCHIN王. trochus, a hoop. Estimated number of species: recent, 556 ; British, 16; fossil, 300. Silurian, \&c.

The shells of the Trochince are found on the coasts of all seas, and exhibit a remarkable variety of form and sculpture.

Group 83.-Sub-Family TURBININ 2 and allies. turbo, a top. Estimated number of species: recent, 110 ; British, 1; fossil, 420 (?). Silurian, \&c.

I Specimens of Turbo and Phasianella, showing the solid stony operculum characteristic of the group. 
Group 84.-Family NERITID應. inpirns, the Sea-snail. The species of Nerita are marine, those of Neritina and Navicella inhabit fresh or brackish water. Estimated number of species: recent, 306; British, 1; fossil, 100. Oolite.

T Clithon longispina, distinguished by a remarkable development of tubular spines; and Nerita peloronta, known to the older conchologists by the name of "The Bleeding Tooth."

\section{Énghth Table Case.}

The Mark 9 indicates specimens or other illustrations exhibited in the cases.

Sub-order PECTINIBRANCHIATA. pecten, a comb ;

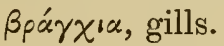

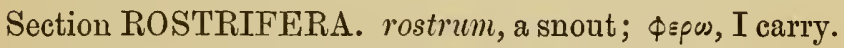

Group 85.-Family ONUSTID瓜 and allies. onus, a load.

Estimated number of species: recent, 158; British, 3;

Fossil, 75. From the Carboniferous upwards.

T Examples of Onustus, Calyptra, Crepidula, Narica, dc., shewing the characters which have suggested the popular names, Cup-and-Saucer Limpet, Slipper-Limpet, Bonnet-Limpet; the Mineralogist Carrier, Conchologist Carrier, \&c.

Group 86.-Family TURRITELLID压 and allies. turris, a tower. Estimated number of species: recent, 124; British, 3 ; fossil, 200 . Tertiary.

T Examples of Turritella, Vermetus, Cacum, Siliquaria, Siphonium, \&c.

In Vermetus, the whorls of an ordinary spiral shell are seen disunited, and taking the form of a cork-screw. 
Group 87.-Family AMPULLARIID压 and allies. ampulla, a globular vessel. Estimated number of species: recent, 181 ; British, 6 ; fossil, 70 . Tertiary.

This family includes the so called Apple-snails, though differing widely from the true snails, which have lungs and are without opercula.

- Ampullaria, Paludina, Paludomus, Bithynia, Nematura, dec., all inhabitants of lakes or rivers.

Upper Compartment.

Ampullaria gigas, from the River Amazon.

Group 88.-Family LITTORINIDE and allies. littus, the sea-shore. Periwinkles. Estimated number of species: recent, 420 ; British, 60 ; fossil, 100. Permian, \&c.

TI Littorina, Rissoa, Planaxis, dic. Litiopa from the Fucus natans in the Sargasso Sea.

Group 89.-Family MELANIID Æ. $\quad \mu e^{\prime} \lambda \alpha \varsigma$, black.

Melania, Melanopsis, \&c. Estimated number of species: recent, 407; British, 0 ; fossil, 72 . Tertiary.

Tा Illustrations of about 30 generic and sub-generic forms, all from fresh water.

Group 90. - Family CANCELLARIID 2 and allies. cancelli, lattice work. Estimated number of species: recent, 274; British, 6; fossil, 720. Trias, \&c.

I Trichotropis, Aporrhais, Cerithium, Struthiolaria, Halia, Admete, \&c.

Trichotropis bicarinata, and a fine series of Cancellaria.

The fossil representatives of this group are very numerous, and are often found in the finest possible condition. 
Group 91.-Family CYPRÆIDA and allies. Cowries. Estimated number of species : recent, 200; British, 3 ; fossil, 64. Cretaceous, \&c.

T Examples of Cyprea, Trivia, Ovulum, Pedicularia. C. aurantia, worn as an ornament by the chiefs in the Friendly Islands.

Upper Compartment.

Very aged C. tigris; C. pantherina, with Balani enclosed in a coating of enamel; and many others from the GASKoIN cabinet.

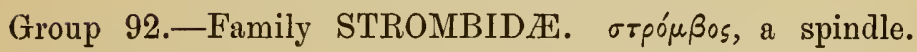
The Strombidæ are active animals, possessing large and well developed eyes : they are by some authorities placed at the head of the Prosobranchiata. Estimated number of species : recent, 84 ; British, 0 ; fossil, 170. Lias, \&c.

T Examples of Pterocera, Terebellum, Strombus, \&c., and a very fine series of Rostellaria.

Upper Compartment.

Rough medallions and finished cameo, from the shell of Strombus gigas.

Section TOXIFERA. $\tau 0 \xi \circ v$, an arrow; $\phi \varepsilon \rho \omega$, I carry.

Group 93.-Family CONID \&. Cone-shells. Estimated number of species : recent, 400 ; British, 0 ; fossil, 80 . Cretaceous, \&c.

If Examples of Conus and Dibaphus, including C.omaicus, C.cedo-nulli, C.nobilis, C. aurisiacus, C. orbignyi, and others, illustrating the generic and sub-generic forms of this highly valued family. 

boscis.

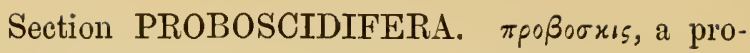
Group 94.-Family SOLARIIDÆ and allies. Solarium, a dial. Estimated number of species: recent, 38 ; British, 0 ; fossil, 400 . Silurian.

I Examples of Solarium =Architectonica, Torinia, \&c., shewing the winding whorls of Solarium, the staircase Trochus. The space is chiefly occupied by fossils, Pleurotomaria, Euomphalus, \&c.

Group 95.-Family TEREBRID王 and allies. terebra, an auger. The Scalidæ, familiarly known as "Wentletraps," seem out of place here, and well deserve to be distinguished as a group by themselves. S. pretiosa, in really fine condition, is one of the most beautiful, as it used to be one of the most costly of shells. Estimated number of species : recent, 480 ; British, 50 ; fossil, 420. Silurian, \&c.

T Specimens of Scalaria, Pyramidella, Eulima, Stylifer, \&c., including Terebra pretiosa from the Dennison cabinet; Niso splendidus, presented by S. Sмгтн; and Stylifer on an Echinus.

Group 96.-Family NATICIDÆ and allies. Estimated number of species : recent, 240 ; British, 11 ; fossil, 260. Devonian.

T Specimens of Natica, Velutina, Lamellaria, Naticina, Sigaretus. 


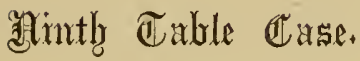

The Mark I indicates specimens or other illustrations exhibited in the cases.

Group 97.-Family CASSIDID $\mathbb{E}$ and allies. cassis, a helmet. Estimated number of species: recent, 80; British, 0 ; fossil, 50. Cretaceous.

T Examples of Cassis, Dolium, Oniscia, Ficula, kce., including Morum exquisitum.

Upper Compartment.

Cameos in various stages (rough medallions, halffinished, and completed), from the shells of C. Madagascarensis and C. rufa. Presented by W. H. Tooke. Sections shewing interior of shells.

Group 98.-Family MARGINELLID必. margo, a rim. Estimated number of species : recent, 412 ; British, 1; fossil, 50. Cretaceous, \&c.

T Marginella, Erato, Columbella, Engina.

Many species of Marginella are unsurpassed by any other shells in beauty of form and finish.

Group 99.-Family MITRID艮. mitres. Estimated number of species: recent, 439 ; British, 0 ; fossil, 100. Cretaceous, \&c.

II Illustrations of most of the $\mathbf{2 1}$ generic and subgeneric forms constituting this extensive and highly ornate family of shells, found chiefly in the Philippine Archipelago. 
Group 100.-Family VOLUTID五. Volutes. Estimated number of species: recent, 100 ; British, 0 ; fossil, 80 . Cretaceous, \&c.

T Examples of Voluta, Cymba, Melo, including the very beautiful and rare Lyria Lyraformis. presented by S. Sмiтtн.

Upper Compartment.

Observe the highly coloured interior of $V$. Ethiopica, Dennison collection.

Group 101.-Family TURBINELLID $\mathbb{E}$ and allies. turbo, a top. Estimated number of species: recent, 118; British, 0 ; fossil, 48 . Cretaceous, \&c.

Turbinella, Fasciolaria, Fastigiella.

Upper Compartment.

Armlets, made from the Chank-shell, and worn by natives in Ceylon.

Curious linear arrangement of egg-capsules, supposed to belong to some species of the present - group. Presented by Captain Mortiner.

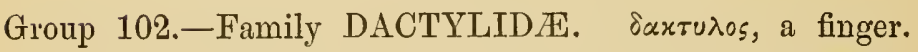
Three very characteristic sub-families are combined in this group, the Olives, the Harps, and the Ancillæ, all tropical or sub-tropical in their distribution. It may be noticed that the present and five preceding groups are represented in British seas by a single species only, and appeared not earlier than the chalk formation. Estimated number of species: recent, 161; British, 0 ; fossil, 70. Cretaceous.

Oliva, Harpa, Ancilla.

T O. Labuanensis, discovered and presented by C. Collinginood.

Upper Compartment.

Malformations. GASKoIN Collection. 
Family BUCCINID $æ$ E. buccinum, a trumpet.

Group 103.-Sub-family PURPURINE and allies. purpura, purple. Estimated number of species: recent, 178; British, 1 ; fossil, 42 . Tertiary.

Tा Examples of Purpura, Ricinula, Concholepas, Separatista, Pinaxia, \&c., comprising a rare variety of Rapana Mawa; Pseudoliva Kellettii. Remarkable specimen of Ricinula clathrata, Dennison collection.

Upper Compartment.

Group of many Magilus antiquns, in coral, Capt. JiNMAN.

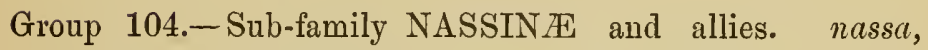
a basket. Estimated number of species: recent, 553 ; British, 7 ; fossil, 150. Tertiary.

T Examples of Buccinum, Nassa, Eburna, Phos, \&c., including a very fine series of Eburna, one species only wanting. S. Sигтн.

Group 105.-Family TRITONIDÆ. Tritons. Estimated number of species : recent, 165 ; British, 0 ; fossil, 68. Tertiary.

T) Examples of Triton, Ranella, Persona, \&c.

Group 106. - Family PLEUROTOMID $\$$. $\pi \lambda \varepsilon u \rho \alpha$, side ; rónos, a notch. Estimated number of species : recent, 491 ; British, 15; fossil, 300. Cretaceous, \&c.

- Examples of Pleurotoma = Turris, Mangelia, \&c. Large number of generic forms. 
Family MURICID艮. Murex.

Group 107.-Sub-family FUSINÆ. fusus, a spindIe. Estimated number of species : recent, 206 ; British, 6; fossil, 340. Oolite, \&c.

T Examples of Fusus, Hemifusus, Pisania, Neptunea Turtoni, \&c.; amongst them, Fusus pagodus and Metula clathrata.

Upper Compartment.

Fusus antiquus, fitted up as in Norway for use as a lamp.

Group 108.-Sub-family MURICINÆ. Estimated number of species : recent, 268 ; British, 6 ; fossil, 180. chiefly Tertiary.

T Examples of Murex, Trophon, \&c., including a very fine series of Typhis, S. Surtr ; and Murex endivia, Dennison collection.

$M$. brandaris and $M$. erinaceus were probably the chief sources of the purple dye for which ancient Tyre was celebrated.

In the Molluses of the next Sub-class occur for the first time in the ascending series animals which have attained to aërial respiration. As compared with other GASTEROPODA, the Land-snails and Slugs possess a similar odontophore or elastic strap, set with sharp teeth; transformations less distinct; a primary neural flexure of the intestine; and breathe air by means of a pulmonary chamber formed by an inflexion of the mantle. 


\section{Tenth $\mathbb{C}$ able $\mathfrak{C}$ ase.}

Sub-class GASTEROPODA PULMONIFERA.

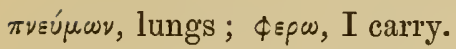

Group 109.-Order OPERCULATA. operculum, a lid. Estimated number of species: recent, 835 ; British, 3 ; fossil, 50; Tertiary. The operculate Pulmonifers attain their highest development in the Polynesian Islands, but are found in botb hemispheres. The shells exhibit remarkable varieties in form and sculpture: some are cylindrical and glassy, others discoid; many are beautifully keeled, as may be seen in the delicately fringed whorls of Trochatella constellata. The drawer is crowded, but contains examples of nearly all the generic and sub-generic forms.

I Cyclostoma, Pupina, Helicina, Truncatella, Assiminia, \&c.

Order INOPERCULATA. in, without; operculum, a lid.

Group 110.-Sub-order THALASSOPHILA. $\quad \theta^{\prime} \lambda \alpha \sigma \sigma \alpha$, the sea; $\phi$ i $\lambda \circ$ s, a friend. Estimated number of species: recent, 98; British, 0 ; fossil, 3. Tertiary.

T Examples of Siphonaria, Amphibola, \&c. The shells of Siphonaria resemble those of the Limpet tribe, but the animals are widely distinct. 72 species are exhibited, most of them presented by Mr. F. P. Marrat.

Upper Compartment.

Drawings of the animals of Siphonaria and Patella. 
Group 111.-Sub-order LIMNOPHILA. $\quad \lambda^{i} \mu \nu \eta$, a pool; $\phi i$ ¿ os, a friend. Estimated number of species : recent, 577 ; British, 25 ; fossil, 160. Tertiary.

IT Examples of Auricula, Scarabus, Limnea, Planorbis, Physa, Physopsis, \&c. A brackish or fresh-water group, as indicated by the pale or. sombre colouring even of the tropical species.

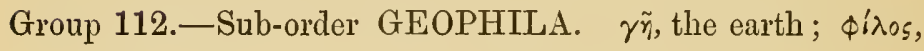
a friend.

Family LIMACID $A$ and allies. limax, a slug. Estimated number of species: recent, 186; British, 13.

T Examples of Limax, Arion, Nanina, Helicarion, \&c. The beautifully coloured shells of Nanina appear to advantage in a group where most of the species are without shells.

Upper Compartment.

Drawings of Animals.

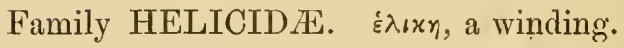

Group 113. - Sub-family HELICINA. Part I. The influence of geographical position is well illustrated in this group, by the family likeness subsisting between the members of the smaller sets, Brazilian, N. American, Madeiran, and European. Estimated number of species: recent, 408 ; British, 10 ; fossil, a few. Tertiary.

T Examples of Solaropsis, Anchistoma, Iberus, Theba, de. 
Group 114.-Sub-family HELICINÆ. Part II. The upturned mouth of Anostoma indicates that the adult animal must move with the spire of the shell downwards. The West Indian tribe allied to Lucerna Macrocyclis includes some of the largest and the smallest of the Helices. Estimated number of species: recent, 200; British, 6 ; fossil, a ferv. Tertiary.

T Examples of Acavus, Cochlea, Lucerna, Macrocyclis, dc., including a fine series of the rare Malayan genus Geotrochus.

Group 115.-Sub-family HELICIN 2 . Part III. Estimated number of species : recent, 200; British, 3 ; fossil, a ferv. Tertiary.

T Examples of Streptaxis, Helix, Helicostyla, de.

In the Philippine Islands the Helices attain their highest beauty of form and colour; e.g., Callicochlias, Corasia, and Helicostyla.

Group 116.-Sub-family PUPINæ. Pupa, a doll. Estimated number of species: recent, 574 ; British, 16 ; fossil, 50. Tertiary.

T Examples of Pupa, Clausilia, Cylindrella, \&c., and of most of the generic forms in this extensive group.

Note the form and sculpture of some of the more slender species of Cylindrella, a West Indian genus.

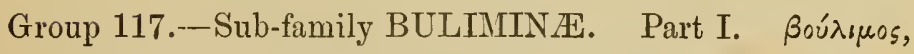
hunger. Estimated number of species: recent, 480 ; British, 5 ; fossil, 0 .

T Examples of Orthalicus, Bulimulus, dc. For the geographical distribution of the Bulimi, see tho tablets.

Note the delicate texture of the shells in the paper 
Bulimi, Orthalicus; the "grotesque shapes in Otostomus; the form, texture, and colour in Aspastus.

Group 118.-Sub-family BULIMINÆ. Part II. The Helices of the Philippine Islands are rivalled by the Bulimi of the same region, e.g., B. irroratus, and B. malleatus. Estimated number of species: recent, 230 ; British, 0 ; fossil, 30 . Tertiary.

T Examples of Cochlostyla, Bulimus, Partula, \&c. Upper Compartment.

$B$. ovatus, and other Bulimi, with their eggs.

Group 119.- Sub-family ACHATININ $\mathrm{E}_{j}$ and allies. achates, an agate. Estimated number of species : recent, 344; British, 3 ; fossil, 14 . Tertiary.

T Examples of Achatina, Succinea, Achatinella, Simpulopsis, \&c.

\section{Upper Compartment.}

Some of the larger Achatina, chiefly an African genus, fully equal in size the largest Bulimi of the western hemisphere.

Group 120.-Family OLEACINIDÆ and allies. olea, an olive. The present is a very heterogeneous group, but all the most important forms are well illustrated. Estimated number of species : recent, 503 ; British, 16 ; fossil, a few. Tertiary.

T Examples of Oleacina, Glandina, Discus, Zonites, Vitrina, Testacella, Sagda, \&c. Series related to Testacella and Parmacella. 


\section{Elebently Cable Case.}

The Mark I indicates specimens or other illustrations exhibited in the Cases. Group 121. Family BELEROPHONTID Æ (MacCoy). Estimated number of species 70, known only as fossils, chiefly Silurian and Carboniferous. The position of the group is uncertain, the animal being quite anknown except through the remains of its shell.

\section{Class CEPHALOPODA.}

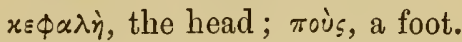

Organs of progression encircling the head.

Order TET'RABRANCHIATA (Owen). Gills 4 ; arms many, without suckers, resembling tentacles. The shells in this very extensive order, of which only a single living form remains (the Nautilas), are all chambered, i.e., divided transversely into compartments, in the outermost of which the animal resides, keeping ap a communication with the previously inhabited chambers by means of a siphuncle or tube.

Family AMMONITIDE (OwEN). "AMM $\Omega$, a title of Jupiter when represented as having the horns of a ram.

Group 122.-Genus HAMITES (PARkinson); and allies. Hamus, a hook. This group includes the genera of the Ammonite family in which the tube of the shell is nearly straight or sharply bent near the extremity; also genus Turrilites, in which the chambered tube forms a beautifully spiral shell. Estimated number of species 140, all known as fossils of the Cretaceous system.

Group 123.-Genus AMMONITES (Bruguiere). Sutures of the shell more or less ramified. Estimated number of species 530, occurring from the Trias to the Chalk.

I Specimens of Ammonites from the Wealden, Oolite, Lias, Chalk, and Green-sand formations. 
Group 124.-Genera GONIATITES (De HaAn); and CERATITES (De HaAN). Sutures of the shell sinuous, but not ramified. Estimated number of species 175, known only as fossils from the Devonian to the Trias.

\section{Family NAUTILIDÆ.}

Group 125.-Genus ORTHOCERAS (BREys); and allies. oppòs, straight; x'śp $\alpha_{5}$, a horn. The Orthoceratites were extremely abundant in the very ancient seas, the Carboniferous Limestone in some parts being almost made up of their remains. The shells sometimes attained a length of six feet. Estimated number of species 200, from the Silurian to the Trias.

Group 126.-Genus NAU'TILUS. vaviíios. Aristotle, B.c. 312. Nautilus, the sole living representative of the vast assemblage of tentacle-bearing Cephalopods, has, it is said, been recognised in every geological formation from the Silurian upwards. The series thus extended includes more than 100 species; 6 species are still living, though the animal has rarely been observed, and was first described by Professor Owen. The Nantilus creeps, shell uppermost, on the bottom of the sea; but it occasionally ascends, and has been seen in shoals floating on the surface after a storm.

II Examples of Nautilus pompilins, N. umbilicatus, $N$. macromphalus, and of a few fossil forms.

Upper Compartment.

Sections of the shell to shew the chambers and the siphuncle. Specimen in liquid of the animal within the shell. 
Order DIBRANCHIATA, gills two; arms, with suckers.

Section DECAPODA. arms ten.

Group 127.-Genus SPIRULA and allies. The shell of Spirula is internal and chambered. Estimated number of species : recent, 4 ; fossil, a few, from the lower Tertiary.

\section{Upper Compartment.}

I Spirula in spirits with the animal entire, very rare. Section shewing the ventral siphon passing through the chambers of the shell.

Group 128.-Family BELEMNITID无. $\beta \varepsilon ́ \lambda \varepsilon \mu \nu 0 \%$, a dart. Belemnites. Belemnoteuthis Actinocamax. The shell is internal and chambered and is protected posteriorly by a cylindrical guard tapering to a point. This guard is the only part commonly found. Estimated number of - species 40, all known as fossils, chiefly from the Lias.

I Specimens from Dr. Mantel's collection, in very fine condition, shewing the horny pro-ostracum, the ink-bag, and the phragmacone.

Group 129.-Family SEPIAD无. Cuttles. $\Sigma \eta \pi i x$. Aristotle, from $\sigma ı u_{n}$, a pouch. The shell is internal, consisting of an oval calcareous plate, shewing at the apex traces of the chambered structure characteristic of the order. Estimated number of species: recent, 30 ; British, 3 ; fossil, 9 . Oxford clay, \&c.

I Fossil remains and recent specimens of cuttlebone.

\section{Upper Compartment.}

Coloured drawings of the animal, and preparations in liquid. 
Group 130.-Family TEUTHIDÆ. Cảlamaries and Squids. reufis (Aristotle). The shell is an internal horny pen. Loligo, Cranchia, Sepiola. Estimated number of species : recent, 90 ; British, 10 ; fossil, 14 . Lias, \&c.

- Parrot-like horny beaks of Squids. Eyes of Cephalopods taken from Peruvian mummies. Upper Compartment.

Pen of Squid four-and-a-half feet in length, collected by Capt. Mortiner in the North Atlantic. Animals of the group in spirits.

Section OCTOPODA. arms, eight.

Group 131.- Family OCTOPODIDE Poulpes. Octopus, Eledone. Estimated number of species: recent, 58; British, 1.

- Tried Octopods, from the market at Constantinople.

Upper Compartment.

Drawings, and preparations in spirits.

Group 132.-Family ARGONAUTIDE. Argonaut, PaperNautilus. The beautiful shell of the female Argonaut is secreted by the extremities of the dor'sal arms, which are disciform. The animal is not attached to the shell, but sits in it, clasping the sides with its webbed arms.

- Very large specimen of $A$. argo, and examples of four other species.

Upper Compartment.

Drawings of the female Argonaut with its shell. Preparation in liquid of male Argonaut, shewing the hectocotylised arm. 


\section{Thelfth Table case.}

The Mark indicates specimens or other illustrations cxhibiled in the Cases.

\section{Sub-kingdom ANNULOIDA.}

Animals possessing a distinct nervous system, a water vascular system, and a food canal shut off from the body cavity: body of the adult having its somites (merosomes) disposed radially.

As the principal departure from the ordinary method of arrangement occurs at this point, it may be proper for the Writer to mention, by way of explanation, that he cannot bring himself to regard the high development of special organs in the CEPHALOPODA, due probably to the absence of morphological obstructions, as in any wise equivalent in importance even to the first prefigurements of the great annulose type; in which many somites, each in itself an individual of a lower grade, unite as constituents, first of a type with an exo-skeleton (Arthropoda), subsequently of a type with an endoskeleton (VERTEBrata), by degrees consigning their combined energies to be under the superintendence, first of a cephalic ganglion, at length of a brain.H. H. H.

\section{Class ECHINODERMATA.}

Exivos, the hedgehog; $\delta$ spua, the skin.

The general arrangement of the groups in this Class is in accordance with the classification adopted by MM. Dujardin and. Hupe, in "Histoire Naturelle des Zoophytes Èchinodermes." (Suites à Buffon. Paris, 1862.) 


\section{Sub-Class CRINOIDA.}

xpivos, a lily; sî́os, form.

Body of the animal, during the whole or a portion of its existence, attached to the sea-bottom by a jointed and flexible stalk.

Group 133.-Orders CYSTOIDEA, BLASTOIDEA, and CRINOIDEA in part. The Cystoidea, earliest of the Echinoderms, attained their maximum in the Lower Silurian. They were closely followed by the Blastoidea, or Pentremites, and the Crinoidea, or Stone-Lilies: the latter alone survived, though in diminished numbers, the Palæozoic age. Estimated number of species, 140. M. Dujardin.

Group 134.-Family PENTACRINIDÆ (D'Orbigny). The beautiful Pentacrinus Mulleri is one of the few living forms which very closely connect the animal life of the present age with that of ages immeasurably remote. Living in the deeper waters of the Caribbean Sea, it has seldom been brought to light, and was long regarded as a solitary relic of the vast Crinoid population of the ancient oceans. Deep-sea dredging has recently afforded examples of allied forms. Pentacrinus Wyville-Thomsoni was taken at a depth of 1,095 fathoms, E. Atlantic, and Bathycrinus gracilis at 2,435 fathoms. Estimated number of species: recent, 6; fossil, 6. Lias.

The collection is fortumate in possessing one fine specimen of P. Mulleri and two of P. WyvilleThomsoni. Whilst inspecting them Dr. Carpenter, who described and named the latter species, remarked to the writer that, in consequence of a structural peculiarity, the stem of 
a Pentacrinite never snapped asunder except at a joint close below one of the whorls of arms which at intervals of about three inches radiate from the stem. If therefore the stem of a living Pentacrinite broke, a whorl was thereby brought in close and even contact with ine sea-bottom, to which the arms could cling and again support the animal in an erect position.

Group 135. - Family COMATULIDÆ. Feather-stars. Although the adult Feather-stars move freely from place to place, in their early condition they are attached by the centre to a fixed stem, in which stage they so much resemble the species of the preceding group, that the larval state of Comatula rosacea received the name of Pentacrinus Europceus. Estimated number of species: recent, 35 ; British, 3 ; fossil, 20.

\section{Sub-Class ASTEROIDA. Star-Fishes.}

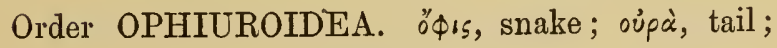

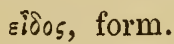

Group 136.-Family OPHIURIDÆ. Part I. Sand-stars. In the Ophiuridx the number of arms is always five; the arms do not, as in the true Star-fishes, contain extensions of the body cavity, but are simply locomotive appendages. Estimate of species : recent, 80 ; British, 2 ; fossil, 9.

I Examples of Ophioderma, Ophiura, Ophiolepis, and other genera. 
Group 137.-Family OPHIURIDÆ. Part II. Brittle-stars. The Brittle-stars are much more active than the Sandstars, and have a tendency to break themselves up into little pieces when captured. They die instantaneously when placed in fresh water. The Ophiuride inhabit almost all seas, and are found occasionally at great depths. Estimated number of species: recent, 65 ; British, 11; fossil, 11. Silurian and upwards. The total number of species of Ophiuridæ, in a list by Theodone Lrana, of Harvard College, U.S., is 164.

T Examples of Ophiocoma, Ophiothrix, Ophiacantha, Ophiomyxa, and other genera.

Group 138.-Family ASTEROPHYDEÆ (DuJardin). This group includes species with arms varying from perfectly simple stems to the highly branched appendages of Asterophyton, one species of which, known as the Shetland Argus, when curled up somewhat resembles the Rose of Jericho (Anastatica Hierochuntia). In moving, the Asterophyton lifts itself along on tiptoe, resting on the extreme ends of the branches, which thus form a kind of cage. The branches divide dichotomously, beginning with the 5 arms; these, by division, produce 10, and these again 20, and so on. In a New England specimen, mentioned by A. AGASSIZ, the terminal branchlets were computed at no less than 81,920. Estimated number of species: recent, 16 British, 1.

I Examples of Asterophyton (LiNck); Euryale (LaMARCK). 


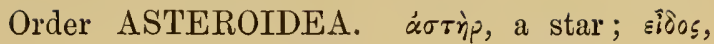
form.

Ambulacral furrows with four rows of tube-feet; anus dorsal.

Group 139.-Genera ASTERACANTHION (MULLER); and HELIASTER (Grax). This group includes the common star-fish or cross-fish, found abundantly on the shores of the Mersey. The arms of star-fishes have, on the under side, furrows pierced with rows of openings through which can be extended or retracted locomotive organs called tube-feet. A complicated apparatus (the water-vascular system) fills or empties, and thus protrudes or withdraws, these tube-feet, or any portion of them, at the will of the animal. Estimated number of species; recent, 50 : British, 4; fossil, 9 . Silurian and upwards. In this, as in most groups of the order, the collection is indebted for fine examples to the liberal contributions of Professor Agassiz.

Ambulacral furrows with two rows of tube-feet; anus dorsal.

Group 140.-Genera CRIBELLA (Agassiz), SOLASTER (Forbes), and allios. The genus cribelle forms a link between the cross-fish, Uraster, and the sun-stars, Solaster. Most of the Echinoderms possess, and Cribella exhibits very distinctly on its upper surface, near the junction of two arms, a small aperture like the rose of a watering-pot (madreporiform tubercle), which acts as a filter for the supply of the water-vascular system. Estimated number of species: recent, 53 ; British, 4 ; fossil, 1. 
Group 141. Genus PALMIPES (Linck), and allies. In this group the arms or rays are slender, so that the web which joins them constitutes the chief part of the body. Palmipes, the Bird's-foot Sea-star, the thinnest and flattest of the order, ranges from the Arctic Seas to the Mediterranean. Estimated number of species : recent, 47 : British, 1; fossil, 7. Higher Crag.

T Examples of Culcita, Asteriscus, Oreaster, \&c.

Group 142.-Genera ASTROGONIUM (Muluer), and GONIODISCUS (MULLER). The long, sharp, and strong spines conspicuous in some of the species of this group serve to protect the animal from the attacks of enemies, or from the effects of sudden concussions. The animal can lower its spines in any required direction, as river steamers lower their funnels when passing under a bridge. Estimated number of species: recent, 30 ; British, 2 ; fossil, 34 . Chalk and Higher Crag.

I Examples of Paulia horrida, Antennea, \&c.

Group 143. - Genera ASTEROPSIS (MULLER), and ARCHASTER (Mulder). Star-fishes, writes A. AGassiz, have a singular mode of eating: they place themselves over whatever they mean to feed upon, - as for instance a cockle, - the back gradually rising as they arch themselves above it; they then turn the digestive sac or stomach inside out, so as to enclose their prey completely, and proceed leisurely to suck out the animal from the shell. Estimated number of species: recent, 11 ; fossil, 2. Green-sand. 
Ambulacral furrows, with two rows of tube-feet: anus absent.

Group 144.-Genera ASTROPECTEN (LrNck) : LUIDIA (FonBes). Three representatives of the present group are found in British seas; Asterias aurantiaca (LINNæUs), Astropecten (Linck), called by fishermen the Butthorn, and two species of Luidia, one of which when full grown measures two feet across, but specimens of this size are with great difficulty obtained entire, owing to the habit which Luidia possesses of voluntarily breaking itself into little pieces when an attempt is made to remove it from its natural element. This species, in common with many others, has at the end of each ray a pigment spot, which is probably a rudimentary organ of vision, and is guarded by a movable eye-lid. Estimated number of species: recent, 46 ; fossil, 20. Oolite and upwards.

\section{Chintenth $\mathbb{C} a b l e ~ \mathfrak{C a s e . ~}$}

The Mark indicates specimens or other illustrations exhibited in the Cases.

Sub-class ECHINOIDA. Sea-Urchins.

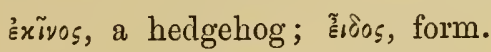

Family CIDARID无. xî́幺pıs, a Persian turban.

Group 145.-Genus CIDARIS (LAMarck) and allies. The globose Cidaride differ widely in appearance from the long-armed Asteride of the preceding order; but if the arms of a star-fish were turned up over its back till the tips nearly met, and if the sides of the turned-up arms were united by plates bearing tubercles crowned with long spines, the morphological affinity between the star-fish 
and the sea-urchin might to some extent be thus illustrated. In the sea-urchin five spaces with ambulacral pores alternate with five spine-bearing segments, all vertically disposed, the mouth being always on the under side. Estimated number of species: recent, 17 ; fossil, 424. Chiefly from the Oolitic and Tertiary formations. I Cidaris papillata (Fleming), the only representative of the group in the British seas, was formerly supposed to be found exclusively near the Shetland Islands, where it is called the Piper, its spines being compared with the drones of a bag pipe.

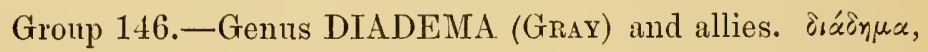
a diadem. The metamorphosis of an echinus has no parallel out of its own class. The egg of the sea-urchin produces a free-swimming ciliated embryo, which becomes a larva with an internal calcareous skeleton, shaped like a painter's easel (Pluteus). On the interior lining of its stomach is formed a germ (blastema), which assumes a radiated form, absorbs in part, or casts off, the larval body with its skeleton, develops a new mouth, and grows into an Echinus. The adult form is therefore constructed on a lower type than that of its larva, from which the sea-urchin seems only to borrow materials necessary for its growth. Estimated number of species : recent, 39; British, 0 ; fossil, 107.

- Examples of Salmacis, Echinocirlaris, Amblypneustes, Garelia, Trichodiadema.

Group 147.-Genus ECHINUS (Linseus) and allies. éxĩos, a hedgehog. In the shell of Echinus sphrer, the common Egg-urchin of British coasts, are combined upwards of 600 plates, bearing more than 4000 movable spines. At the apex is an anal opeuing, surrounded by plates perforated to admit the passage of the ova. One plate, 
larger than the rest, is of a spongy character, and admits water for the supply of the water-vascular system. Five smaller adjacent plates have orifices answering to the eye-specks of star-fishes. On the under side of the Echinus may be seen the points of five projecting teeth, forming the extremities of a marvellously complicated dental apparatus, which has been termed Aristotle's lantern. Estimated number of species: recent, 19 ; British, 3 ; fossil, 26 . Cretaceous and Tertiary.

- Examples of Spherechinus, Lytechinus, Psammechinus.

Group 148. -Genus TOXOPNEUSTES (Agassiz) and allies.

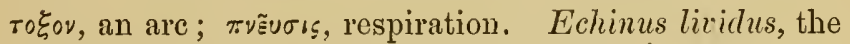
Purple Sea-urchin, was seen by the writer, lying hundreds together in tide-pools on the coast of Kerry, Ireland. This species frequently lives in cup-shaped cavities of rocks corresponding with the size of the animal. It seems to perforate the rock by the continued motion of its spines, which being covered by a living membrane, are renewed at the tip as the points are worn away. Estimated number of species; recent, 30 ; British, 1 ; fossil, 9.

- Examples of Loxechinus, Toxocidaris, Heliocidaris, 'Tripneustes.

Group 149. - Genus ACROCLADIA (Agassiz). äxpos, pointed; $x \lambda a \delta o s$, the young shoot of a tree. The species of this group, distinguished by their massive spines, are found in Tropical seas, and during life are superbly coloured; but they are much disposed to cast off their spines on being removed from the water. Estimated number of species: recent, 6 .

T Examples of Podophora and two species of Acrocladia, very fine. 
Group 150.-Genus ECHINOMETRA (Breynius):: and allies. On the integument of many of the Echinodermata are found curious little appendages called Pedicellarix, in shape not unlike the head; and stem of an Encrinite, but possessing only two or three arms, which open and close with much activity. As in the case of the avicularia of the Polyzoa, their true character is yet unknown. Estimated number of species in the present group: recent, 14 ; fossil, 195.

Family CLYPEASTRIDÆ. clypens, a shield; astrum, a star.

Group 151._Genus ECHINARACHNIUS (VAN PHELs) and

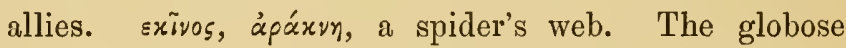
form of the common Sea-urchin differs very widely from the flattened dise of the Cake-urchin, Echinarachmitus placenta, a northern form rarely found in British seas; but upon examination the true ambulacral pores of the Cake-urchin may be seen, forming a rosette on its upper surface; and other very curious modifications of the ordinary echinoil structure may be recognised as associated with an extreme reduction in the size of the body cavity of the animal. Estimated number of species : recent, 32 ; British, 2 ; fossil, 63.

- Examples of Melitta, Dendraster, Rumphia, Lobophora, Scutella.

Group 152.-Genus CLYPEASTER (LAMARck) and allies. Shield-stars. Between the Clypeastride of the present and the Spatangide of the succeeding group occurs the family Cassidulide, in which the mouth is central, but the dental apparatus is wanting. The species, of which M. Dujardin recognises more than 260, begin to appear 
in the lower Oolite, attain their maximum in the Chalk, diminish progressively in the Eocene and Miocene, whilst the living representatives are confined to two or three species found in tropical seas. Estimated number of species : recent, 18; British, 0 ; fossil, 285.

T Examples of Rotula, Encope, Pygorlyynchus, \&c.

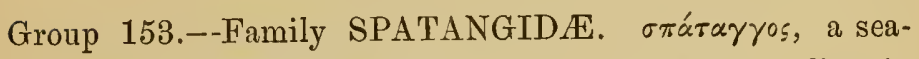
urchin. The Spatangidæ, or Heart-urchins, live in sand or mud, with which when opened their intestines are found to be filled; these substances seem to have been swallowed for the sake of the animal matter mixed up with them. Estimated number of species: recent, 33 ; British, 4 ; fossil, 176. From the Chalk upwards. T Examples of Meoma, Desoria, Xanthobrissus, Tripylus, Plagionotus, Schizaster, Kleinia.

Group 154. - Sub-Class HOLOTHUROIDA. ónotoúpiov, Greek name for the animal. Many links are missing between the Sea-urchins and the Sea-cucumbers, Holothuride. The latter are worm-like animals, possessing a tough flexible skin, and bearing around the mouth a fiverayed coronal of feathery tentacles. The order includes two families: I. Synaptidce, simple in form, and moving by means of anchor-shaped spicules attached to papillæ or minute warts. II. Holothuride, several species of which are known in commerce as Bèche-de-mer or Trepang, used in China as turtle is used in this country. Estimated number of species: recent, 97 : British, 15.

I Exampies of Trepang as prepared by Malays for the Chinese market. Coloured drawings of some of the species, and of their internal anatomy. Specimens preserved in liquid. 


\section{Class SCOLECIDA.

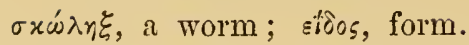 \\ Unisegmental Worms (RoLLeston).}

The head of the Tape-worm constitutes the true animal, the joints being simply hermaphrodite generative products, which the head throws off by a process of gemmation.

Group 155. - PARASITIC SCOLECIDA; often termed ENTOZOA. Tape-worms and Cystic-worms, Teniada; Flukes, Trematoda; Thorn-headed Worms, Echinorhynchus; Hair-worms, Gordiacea; Thread-worms, Ascaris, Oxynuris, Trichina; Guinea-worm, Filaria; \&c. The members of this group may in a general manner be described as passing through certain stages of their development in the bodies of living animals. The embryos when set free remain imperfectly developed until received into some living animal other than the one in which they began their existence.

T Illustrative drawings and diagrams.

Group 156.-FPEE SCOLECIDA. The free, or non-parasitic Scolecida include animals belonging to both the two systematic divisions of the class. In the division Platyclmia, or Flat-worms, are the Turbellaria, including the Planarians, which in shape resemble minute soles, and are found in pools and moist places; also the Nemertians, or Ribbon-rorms, interesting as resembling the Sea-urchins in a certain stage of their larval development. In the division Nematelmia, or Threadworms, most of which are parasitic, are the Anguillulide, Vinegar-eels, Paste-eels, \&c., numbering more than 200 species, chiefly remarkable for tenacity of life. On the authority of Professor Rolleston, a place in this class is assigned to Sagittu, a transparent worm-like marine 
animal about an inch in length constituting, according to Professor Huxuey, the class Chetognatha. Formerly included with the INFusoria, but now generally regarded as a sub-class of ScoLECIDA, occur the Rotifers or wheel-bearing animalcules, familiar, and from their extreme beanty a source of high gratification, to all microscopist observers of pond-life. Rotifera and Turbelilaria possess a "water-vascular system."

T Coloured drawings of Planaria, Sagitta, and Rotifers, including Melicerta and Floscularia. Diagrams illustrating the biology of the group.

trourtenth $\mathbb{C a b l e ~} \mathbb{C}$ ase.

The Mark T indicates specimens or other illustrations exhibited in the Cases.

\section{Sub-kingdom ANNULOSA.}

Animals composed of numerous annular somites or segments arranged longitudinally.

\section{Province ANARTHROPODA. \\ Multisegmental WORMS (Rolleston).}

The Chetognatha being removed to the AnNoloida, on authority as given above, this Province includes a single Class only.

\section{Class ANNELIDA.}

The only systematic work on the species of the whole class known to the Writer is "Histoire Naturelle des Annelés Marins et d'eau douce." M. A. De Quatrefages. 3 vols. 8 vo. and 1 vol. of plates. About 1200 species are described.

No Annelide has a heart or a head comparable with these organs as found amongst Crustaceans or Insects. The water-vascular system generally present in the ANNuloida is here replaced by a pseudo-hæmal system conveying a fluid sometimes corpusculated. The lateral appendages of the segments, when present, are not articulated but pertain to the skin. 
Group 157.-ANNELIDA ABRANCHIATA. Worms unprovided with external organs of respiration.

I. Order Hirudinea = Discophora. Aquatic worms without lateral appendages of any kind, but having a sucking disk posteriorly or at both extremities. Ten genera are included, the forms best known being the Black-leech, the Horse-leech, and two species of the common or medicinal Leech usually imported from Hungary. The latter have ten minute eyes arranged in the form of a horse-shoe over the upper part of the anterior sucker.

II. Order Oligocheta. Earth-worms, Lumbricida, possessing eight rows of short bristles acting as locomotive organs. The animals are eyeless, and have a mouth without appendages. Water-worms, Naidide, including Tubifex, a little bright-red worm inhabiting the mud of impure streams.

III. Order Gephyrea. $\gamma^{\prime} \notin u p \alpha$, a bridge; often regarded as a Class, but recognised by Mr. HuxLey as a division of inferior rank. The animals have affinity with the Holothurians, a fact to which the name may possibly allude, if it does not rather refer to the long strangulated neck of the Spoon-worms, Sipunculida, frequently found on British coasts burrowing in the sand or inhabiting the deserted shells of Whelks.

Group 158.-ANNELIDA BRANCHIATA. Worms provided with external gills in the form of respiratory tufts or plumes.

I. Order Tubicola. In this Order the gills are placed near the head of the animal, forming plumes often of extreme beauty in colour and disposition. The tube may be calcareous as in the little Spirorbis abun- 
dant on Fuci; and in Serpula, the meandering tubes of which frequently almost cover the valves of marine shells; or it may be formed of grains of sand and fragments of shells as in Terebella; or it may be of a leathery consistence, made up of mud strengthened by a glutinous secretion, as in Sabella which at Hilbre may be seen rendering the deeper tide-pools gay as a border of flowers. In Serpula one of the plumes carries a little calcareous lid closing the mouth of the tube when the animal retires.

II. Order Errantia. In the free Annelides the gills are arranged in tufts along the back or sides of the body. In the Sea-mouse, Aphrodite, the back is protected by scales concealing the gills, the scales being themselves hidden by bundles of flexible bristles glittering like spicular iron ore, and displaying all the colours of the rainbow. The Lob-worm, Arenicola, burrows in the wet sand, and is much used by fishermen for bait. In the Sand-worms, Nereide, the anterior extremity is sometimes furnished with eyes, and a mouth with jaws and feelers, and thus makes a nearer approach to a true head than is found in any other of the Verues. Eunice gigantea attains a length of four feet, and has as many as four hundred segments. The tracks and burrows of the free Annelides on the ancient sea-bottoms are found in rocks of àlmost all ages from the Cambrian upwards. The tubes of the Tubicola occur as early as the Silurian period. The little Microconchus was found by the writer in the middle coal-measures at Ravenhead. 


\section{Province ARTHROPODA.}

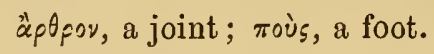

Animals with jointed limbs articulated to the body.

This great Province vastly outnumbers in species the total of. the preceding invertebrate Provinces, and exceods them in the interest of its annals. The gathering up of several body-segments, somites, to form a true head, here first appears, and with it apparently a capacity for the higher orders of instinct. Prefigured in VERMES, this arrangement attains perfection by multitudinous steps and very slow degrees. The term ARTHROPODA is retained as a convenient designation, but is inferior to ANNDLOSA in expressing the chief character of the present Sub-kingdom.

\section{Class CRUSTACEA. crusta, a crust.}

Respiration generally by gills. Antennæ, two pairs. Jointed appendages, more than eight. The body of a typical Crustacean is made up of about twenty-one segments or somites, often nearly equally distributed between the head, the thorax, and the abdomen.

The general arrangement of the Class is in accordance with the "Histoire Naturelle des Crustaces," par M. MiLne Edwards; but advantage has frequently been taken of the great work on the same subject by JAMES DANA, of the United States Exploring Expedition: this work is a monograph of surpassing excellence.

Sub-class CIRRIPEDIA. cirrus, a curl; pes, a foot.

In the larval state the Cirripedes are free and locomotive: subsequently two of the larval antennæ discharge a kind of glue, by which the head of the animal becomes permanently attached to some solid object.

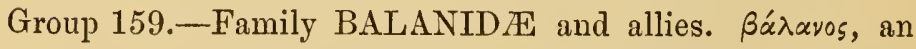
acorn. In the family of Sessile-cirripedes, or Acornshells, the head of the animal is fixed to the centre of a shelly plate, the basis of a conical shell made up of 
several pieces and open at the top when not closed by the pyramidal operculum. To the thorax are attached six pairs of forked limbs bearing twenty-four plumes or cirri. Rocks and stones near low-water mark for miles together on various parts of the British coasts are thickly coated with Balanus crenatus; other species are found attached to Cetacea, Turtles, shells, and corals. Balanus psittacus attains a height of eight inches, and is much prized as an article of food in Chili. Estimated number of species: recent, 100 (DARWIN); British, 16.

Group 160. - Family LEPADID正. $\lambda \varepsilon \pi \dot{\varepsilon} s$, the Limpet. Stalked Cirripedes, or Barnacles. The antennæ of the free larva are prehensile. Having attached itself to some solid object, as a piece of timber or the bottom of a ship, the anterior extremity of the animal becomes enormously elongated forming a stalk or peduncle bearing a "capitulum," constructed of calcareous plates united by a membrane. Delicate plumes made up of twentyfour cirri are incessantly protruded and retracted and by their action currents of water are made to enter the capitulum bringing food to the animal. The plates of the capitulum are extensively used in the construction of artificial flowers.

The remainder of the Sub-class includes two interesting but minute species, constituting the orders Abdominalia and Apoda. Estimated number of species : recent, 45 (DarwIN); British, 11.

Sessile Cirripedes are first met with in Eocene deposits; and Stalked Cirripedes have been found as early as the lower Oolite; but neither appear in any age to have abounded so greatly as at the present time. 


\section{Sub-class ENTOMOSTRACA.}

In the third or highest Sub-class of Crustacea, viz., Malacostraca, the post-cephalic segments are fourteen in number: in the ENTomostraca the number is greater or less than fourteen.

Group 161.-ENTOMOSTRACA, in part.

I. Order Ostracoda. ï $\sigma$ tparov, a shell. Animalcules abundant in fresh-water pools. The body is enclosed in a bivalve shell. Cypris, \&c.

II. Order Copepoda. $x \omega \pi n$, an oar ; $\pi$ où $\varsigma$, a foot. Water-fleas, Cyclops, \&c.; head and thorax protected by a carapace. The Fish-lice, Ichthyophthira, including Lernce, Achtheres, Peniculus, and various other genera parasitic on fishes, are recognised by Professor HuxLeY as peculiarly modified COPEPODA.

III. Order Cladococera. $x \lambda \alpha \alpha_{\delta} \delta s$, a branch; $x$ śpas a horn. Antennæ used in swimming. Daphnia, \&c.

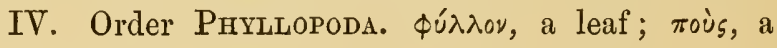
foot.

Fairy-shrimps, \&c. Apus, interesting from its affinity to the extinct Trilobites, is said to have sixty pairs of feet. Estimated number of species : recent, 190 (M. Edwards); fossil, 70. From the Silurian upwards.

Some of the smaller species, both fresh-water and marine, swarm in numbers beyond computation. Active and voracious, they in their turn become the prey of enemies of many kinds: the redness and flavour of trout are supposed to be improved by a diet of EntoMostraca: the crystalline texture of Beroë discovers them undergoing the process of being digested; and water-drinking animals of all orders, in the absence of extreme precautions, derive some part of their nourishment from minute Crustaceans. 


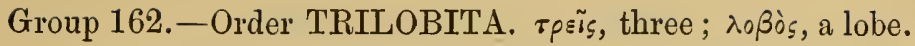
The species of this order are known only as Palrozoic fossils. The eyes when present are compound, but no antennæ or gills have been detected, and very little is known of their locomotive organs. BurueIster thought that the Trilobites swam, back downwards, in shoals near the coast, rolling themselves into a ball as a defence when attacked. Dr. BuckLand compared them with Serolis (see Group 164).

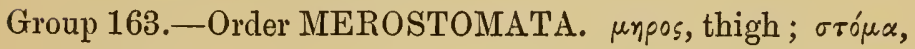
mouth.

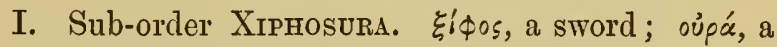
tail. The King-crab, Limulus, seen from above, exhibits little more than a huge buckler rounded in front and furnished with a pair of large dull eyes and three ocelli; a second smaller buckler toothed at the sides; and a posterior appendage, or telson, shaped like a bayonet. From below, the animal thus esconced appear's as if chiefly made up of an assemblage of jointed limbs, of which six pairs encircle the mouth, the basal joints or thighs acting as jaws, whilst the extremities serve for prehension or locomotion. Six other pairs carry gills and are used in swimming. The species are not numerous but frequent sandy coasts in many parts of the world, and occasionally leave the water, burying themselves in the sand to avoid the heat of the sun. The King-crabs were in existence before the Trilobites disappeared. The long continuance of so grotesque a form, resembling a magnified animalcule, is worthy of notice.

II. Sub-order Eurypterida. súpùs, broad; $\pi \tau \varepsilon$ pò, a wing. The species are known as Palæozoic fossils.

T Four species of Limulus, and a small example of Pterygotus, a genus of fossil Crustaceans, some species of which attain a length of six feet. 
Sub-class MALACOSTRACA. The third and highest sub-class of the Crustacea. The body-segments (somites) are regarded as being twenty-one in number, of which seven are cephalic (belonging to the head), seven thoracic, and seven abdominal; but the whole of these can be distinguished in no single example. The modifications of the segments and their appendages are extremely complicated: one rule however obtains in all instances, namely, that each pair of appendages indicates a separate segment.

Division EDRIOPHTHALMATA. $\varepsilon_{\varepsilon} \delta \alpha$, a seat;

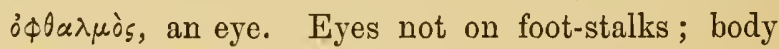
not protected by a carapace.

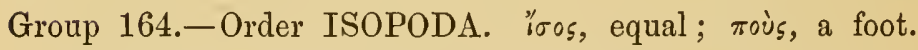
The animals of this group generally possess seven more or less uniform pairs of feet which in the three sections of the order are modified to suit various modes of life.

I. Cursorial. The Sea-slater, Ligia, common on walls near the sea. The wood-piercing Isopod, Limnoria terebrans, wherever it prevails, notwithstanding its small size, is a most destructive enemy to ships, piers, and timber embankments. The Wood-lice, Oniscus, and the Pill-balls, Armadillo, though terrestrial, breathe by modified gills.

II. Natatorial. The Sea Pill-balls, Sphceroma, swim freely, but the Fish-lice, Cymothoa, remain for the greater part of their existence attached to fishes.

III. Seclentary. The Prawn parasite, Bopyrus, may sometimes be detected under the carapace of a prawn, where the Isopod probably feeds together with, rather than upon, its host.

Estimated number of species: recent, 210; British, 42. 
T Examples of Idotea entomon, from the Baltic, the largest of the Isopods; Serolis, from the Falkland Islands.

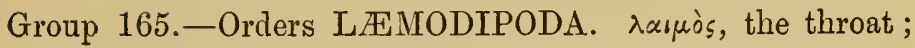

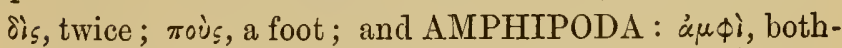
ways; $\pi \circ \dot{y}_{s}$, a foot. The species in the former order are few and possess heads indistinctly separated from the thorax; hence the first pair of limbs seem to be attached to the throat. The order includes the Skeleton-screw, Spectre-shrimp, and the Whale-louse, Cyamus. From the Isopods the Amphipods differ in having pairs of limbs set both-ways, to the front and to the rear. Amongst them are the Sand-hoppers, Talitrus, which occur in millions near the water's edge on sandy coasts, incessantly leaping as if overflowing with the joy of life (PALEY). The Coast-screw, Gammarus; the xylophagous Chelura; and the tube-inhabiting Cerapus. Estimated number of species: British, 110.

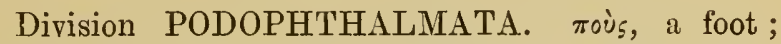

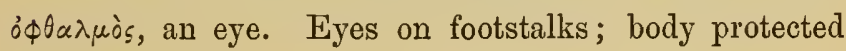
by a carapace.

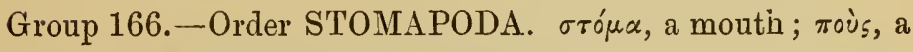
foot. Gills external; pairs of legs, generally seven. The Opossum-shrimps, Mysis, so called from the pouch in which the female carries her eggs, abound in some parts of the Aretic Seas. On the coast of Boothia they form the food of prodigious shoals of salmon: in the Greenland Seas two species form part of the food of the common whale. Mysis Oberon, found on the coast of Cornwall, is so transparent that in a tumbler of water nothing of it can readily be seen but its pair of black 
eyes. The Squilla, or Mantis-shrimp, so called from its resemblance to an Orthopterous insect, exhibits most of the body segments with their appendages perhaps better than any other Crustacean. The larger species are tropical, and it is probable that the animal, like the Mantis, waits the approach of its prey within the reach of its truly formidable fore-legs. Estimated number of species : recent, 50 (M. Edwards); British, 18.

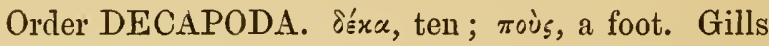
contained in cavities at the sides of the carapace. Pairs of feet, five, the first pair at least chelate, i. e. terminated by nipping claws. Includes Shrimps, Prawns, Lobsters, and Crabs.

Many of the finest examples were obtained from W. HARPER $\mathrm{P}_{\mathrm{E} A \mathrm{SE}}$, by whom they were collected in the Pacific.

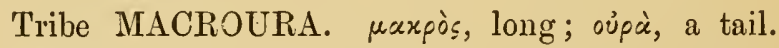
That which is commonly called the tail is in reality made up of segments of the abdomen, which in the present tribe is terminated by a fan-shaped swimming appendage or fin, obviously acting to the greatest advantage when, by its powerful down-stroke, it propels the animal backwards.

Group 167.-Family PALEMONIDE. Prawns, Palemon, differ from Shrimps in the position of the segments bearing the antennæ, and in the carapace, which in the Prawn is generally keeled and extended in the form of a sharply-toothed beak, but in the Shrimp is depressed and unarmed. Prawns whilst living are objects of great beauty, and in warm climates often exhibit vivid colours and attain a large size. Mr. Gosse notices the curious fact that Prawns taken from the obscurity of deep holes 
and rocky pools reflect a rich flush of iridescent purple extending over the whole body, heightening in effect the various streaks and spots of orange, light-blue, red, chestnut, and cream-white which adorn the animal. These disappear, though the animal may continue in health, after a few hours' exposure to the light; and specimens captured from shallow pools have even when first taken all their markings of a pale-olive tint. Estimated number of species, 42 (M. Edwards); British, 11 (BELL).

ๆ Examples of Rhynchocinetes, Hippolyte, and Palcmon, including $P$. carcinus and $P$. Jamaicencis.

Group 168.-Families CRANGONID $Æ$, ALPHEID $Æ$, and PENÆIDA. Shrimps, Crangon, exhibit a tendency the reverse of that noticed in Prawns, the species found in Northern Seas being frequently larger than those belonging to the more southern coasts of Britain. In the Arctic seas and in the bays of Spitzbergen they supply food to the Walrus and the Seal (Adam White). Estimated number of species : recent, 52 ; British, 10 (BELL).

व Examples of Crangon, Atya, Sicyonia, Alpheus, including Crangon borealis.

This group, together with the preceding = Famille des Salicoques (M. Edwards).

\section{dfiftecently $\mathbb{e} a b l e \mathfrak{C} a s e$.}

The Mark indicates specimens or other illustrations exhibited in the Cases.

Group 169.-Families THALASSINIDÆ and ASTACIDÆE, excluding Homarus. The former of these families includes the burrowing $\mathrm{M}_{A C R O U R A}$, generally found buried 
in sand or mud: the body is long and weak and the shell or crust membranaceous. Some of the exotic species have the power of occasionally leaving the water and remaining out of it for a considerable time.

Astacus, the River Cray-fish, is found in freshwater streams, especially near old bridges, where cracks in the masonry afford it a safe retreat.

Nephrops, the Norway Lobster, is generally a northern species, though Mr. BELL mentions having received fine specimens from the Mediterranean.

Estimated number of species: recent, 24; British, 7.

Group 170.-Genus HOMARUS (M. Edwards). Lobster. The CRustaoes all cast their shells annually, or more frequently, until they arrive at full growth. In the presence of the gigantic variety of the common Lobster, Homarus vulgaris, found on the coasts of North America, it seems impossible that the huge mass of muscular flesh contained in the large claws should be withdrawn through the narrow joints without being crushed and destroyed. Reaumur states that the segments are composed of two longitudinal pieces which open to allow of the withdrawal of the soft limb, and afterwards close again so accurately that it is very difficult in the cast crust to discover the line of division. This explanation, derived from observations on the River Cray-fish, has not met with general acceptance, aud the method of the moulting, ecdysis, of the higher Crustacea is still open to discussion.

Estimated number of species : recent, 3 (M. Edwards); British, 1.

4 Example of common Lobster, and of the gigantic American variety. 
Group 171.-Family PALINURID无. The Spiny Lobsters are undoubtedly amongst the most handsome of the Macroura; but the group is chiefly interesting from the fact that the Glassy-Crabs, Phyllosoma, till recently supposed to be included in the Stomapoda, are now recognised as larval forms of the Palinurida. In Astacus and Homarus, the young, from the time when they are very small, are said closely to resemble the adult. If this be true, the affinity between the Lobsters and the Spiny Lobsters is probably simply a morphological one, and points of great interest may be expected to occur during future investigations of the physiological character of the Spiny Lobsters. The species are widely distributed, and are found on rocky coasts.

Estimated number of species: recent, 13; British, 1.

T Examples of P. guttatus, P. Lalandii, P. longimanus, \&c., and of Phyllosoma.

Group 172.-Families SCYLLARID $Æ$ and GALATHEID Æ. The Broad-lobsters, Scyllaride, derive much of the peculiarity of their form from an extraordinary modification of the outer pair of antennæ, which in this family are developed into broad flat plates, sometimes strongly toothed on the margin and probably serving for shovels in excavating holes in the sea-bottom, in which the animals take shelter whilst watching for their prey.

The Plated-lobsters, Galatheida, resemble the preceding in habit. $\mathrm{Mr}$. Couch observes, with reference to Galathea strigosa, "It is very remarkable to witness the accuracy with which they will dart backward for several feet into a hole very little larger than themselves; this I have often seen them do, and always with precision." 
The arrangement of M. EDwards is followed in the retention of Galatheidle in the tribe Macroura.

Estimated number of species : recent, 18; British, 5 .

T Examples of Scyllarus, Ibacus, and Galathea; and of Eglea lavis, a fresh-water species from Chili, collected and presented by Capt. J. A. Perry.

Tribe ANOMOURA. ävoros, irregular ; oủpà, a tail. The Crustacea of this tribe exhibit an advance in organisation, the anterior or cephalo-thoracic portion of the body being more developed in comparison with the abdominal portion than in the Macroura.

Group 173.-Section ANOMOURA INFERIORA (DANA) in part.

Sub-tribe PAGURIDEA. Hermit-Crabs.

In the Soldier-crabs, or Hermit-crabs, the abdomen is long, weak, and tender ; it is therefore inserted into the cavity of some cast-off marine shell, of which the crab becomes the tenant, changing however its habitation for a more commodious one as it increases in size. Shells occupied by $P$. Prideauxii, a British species, very frequently afford a resting place for the Sea Anemone, Adansia maculata. Within the shell, together with the crab, a beautiful sea-worm, Nereis bilineata, often resides, seizing and devouring without molestation a share of the food captured by the crab.

The Purse-crab, Birgus latro, inhabits many islands in the Pacific, living in holes at the roots of trees, and only occasionally visiting the sea. It feeds on the nuts of various palms, and is said to climb the cocoa-nut trees in search of its favourite food.

Estimated number of species : recent, 43 ; British, 10.

T Examples of Cenobita, Calcinus, \&c. 
Group 174.-ANOMOURA SUB-MEDIA. DANA.

Sub-tribe LITHODEA. Stone-crabs.

Not more than about six species are known belonging to this group.

9 The Northern Stone-crab, Lithodes Maia, is found occasionally on the coasts of Scotland and the Isle of Man. The colour whilst the animal is living is yellowish red; that of an allied species from Fuegia is cherry-red. The Porcupine Stone-crab, Lithodes hystrix, is from Japan. The Noduled Stone-crab, Echinocerus cibarius, is from the Columbia River. It is probable that all the species are weak slowmoving animals, and that their strange aspect corresponds in some way with their more than ordinary need of protection.

Group 175.-ANOMOURA MEDIA. DANA.

Sub-tribe YORCELLANIDEA. Porcellain-crabs.

The little Porcellain-crabs are the butterflies of the class. Many species frequent coral reefs and as described and figured by D'ORBIGNy and other writers exhibit elaborate ornamentation and vivid colouring. One species is wholly of a bright scarlet-lake, another of a deep mazarin-blue, a third is rose-colour, with bands of snow-white fringe crossing the carapace; other more sombre species, including the "Broad-claw" of our own coasts, have series of long and delicate lashes, serving as nets or strainers for the capture of animalcules. The Hippidea are small Crustaceans found chiefly in the Pacific.

Estimated number of species: recent, 34 ; British, 2.

१ Examples of Porcellana, Remipes, Albunea, \&c. 
Group 176.-ANOMOURA SUPERIORA. DANA. Sereral species of Dromia carry on the carapace a sponge-like mass of sufficient size to conceal the whole animal. M. Edwards remarks, that the Dromia fixes the load on its back by the aid of its posterior pair of legs. Some other crabs have similar habits, in consequence of which the older individuals resemble walking gardens of various kinds of Zoophytes. Mr. T. HIGGIN observed in the young of Hyas coarctatus that its bristles were sharply recurved at the point, forming a forest of hooks capable of entangling loose sprays of Zoophytes and Sponges, some of which would take root and at length form a thicket, under cover of which the robber crab might readily make a prey of unwary intruders.

Estimated number of species : recent, 12 ; British, 1.

T Examples of Dromia, Dynomene, Homola, Ranina, \&c.

Tribe BRACHYURA. Bpaxìc, short; oupà, a tail.

This tribe includes all the most highly organised Crustaceans. The nervous system is much more concentrated forwards than in the inferior tribes. The abdomen is slightly developed, and is not used to assist the animal in swimming. The larval form, Zoea, long considered to be a distinct animal, bears some resemblance to the adult type in the Macroura.

Section A.-Crabs with mouths much narrowed in front = Famille des Oxystomes (Milne Edwards).

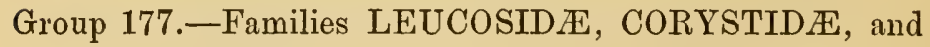
DORIPPIDAE.

Many of the Leucoside are readily distinguished by their convex form narrowed in front into a kind of 
muzzle, and by their porcellanous shells smooth or granulated. They are tardy animals resting with their bodies covered up to the eyes in sand, often in deep water.

The Corystide are placed by Dana considerably higher in the series. The external antennæ are long and hairy. One species of Corystes inhabits British seas, and is called the Masked-crab.

Dorippida. The two posterior pairs of legs in these degraded-looking crabs are situated on the hinder part of the back, and are adapted for clasping.

Estimated number of species : recent, 60 ; British, 6 .

T Examples of Peltarion, Pseudo-corystes, Persephona, Ilia, Ixa, \&c.

Group 178.-Family CALAPPID无. Nearly every species in this limited group is distinguished by striking peculiarities in form or colouring; but very little seems to be known of the life history of any one of them. The Mediterranean representatives of Calappa are called by the French Crabes Honteux, Modest-crabs, from their habit of hiding their beads and smaller limbs behind their broad-crested nippers, chela. The armour is certainly strong and very complete, and might be of invaluable service to the wearer if a Calappa had nothing to do but to defend itself from the attacks of enemies; but how a panoply allowing the limbs but little play can be convenient for the general requirements of crablife has yet to be discovered, and perhaps may be by the aid of an aquarium.

Estimated number of species: recent, 18.

T Examples of Matuta, Hepatus, Camara, Orithya mamillaris, \&c. 
Section B.-Crabs with quadrilateral shields = Famille des Catometopes (Milne Edwards).

Group 179.-Family GRAPSID E. This family includes seven genera, the species of which are widely distributed through tropical and sub-tropical regions: they frequent coasts and rocks washed by the spray of the ocean, and are very timid creatures, retreating on the first alarm with great speed to their lurking places. Nautilograpsus alone is oceanic in its habits, and is found on floating timber or sea-weeds, often far from land.

Estimated number of species: recent, $60 ;$ British, 1.

T Examples of Goniopsis, Sesarma, Trichopus, Plagusia, \&c.

Group 180.-Families OCYPODID Æ and GONOPLACIDA. The Ocypodians, as the name implies, are very swift runners, being nearly always on the strand where they dig holes in which for the most part they remain during the day, coming forth to feed at night. They are said to hybernate in holes further from the sea. The species of Gelasimus are remarkable for the enormous size of the claw on one side of the male crab : they live together in pairs in holes on the beach: the large chelæ are used to defend the entrance to the hole.* The Gonoplacians are good swimmers, and are generally found

* My friend, Canon Kingstex, describes the demeanour of this Crab as irresistibly ludicrous: "One of his claw arms, generally the left, has dwindled to a mere nuthing and is not seen; while along the whole front of his shell lies folded one mighty arm on which he trusts; and with that arm, when danger appears he beckons the enemy to come on, with such wild defiance that he has gained therefrom the name of Gelasimus vocans, 'The Calling Laughable': and it were well if all scientific names were as well fitted." ("At Last," vol. ii., p. 89.") 
in moderately deep water. The spēcies are not well defined: one of the forms occurs in British seas.

Estimated number of species : recent, 32 ; British, 1.

I Examples of Curtonotus, Macrophthalmus, \&c.

\section{Siztently Table Case.}

The Mark If indicates specimens or other illustrations exhibited in the Cases.

Group 181.-Family GECARCINID $\approx$ and allies.

This group includes four families, well distinguished by the habits as also by the structure of the animals.

The Thelphusidae are fresh-water crabs, living in holes on the banks of rivers.

The Gecarcinidce, as the name implies, are Landcrabs, inhabiting the warmer regions of all parts of the world, except the interior of continents. Their gills are adapted for respiration so long as they are kept moist, a condition favoured by the nocturnal habits of the animals. Once in the year, at the spawning season, they are said to migrate in vast number's together, always taking the nearest way to the sea.

The Pinnotherida, or Pea-crabs, reside in the bivalve shells of living Molluses.

The Mycteride for the most part inhabit saltmarshes.

Estimated number of species : recent, 50; British, 2.

Tा Examples illnstrating the four families. 
Section C.-Crabs with shields more or less semicircular in front $=$ Famille des Cyclonetopes (Milne Edwards).

Family PORTUNIDE. Crabs with hinder tarsi much dilated, for swimming.

Group 182--Genus CHARYBDIS (De HaAN) and allies. In the large division of the Crustacea characterised by having organs of vision set on long footstalks, Podophthalmus vigil, in this group, an inhabitant of tropical seas, affords the most striking example of pedunculated eyes, the special advantage of which to the animal has not been fully ascertained; but it seems certain that by such an arrangement the animal might compute the distances of objects of prey very accurately by their parallax, and might view them stereoscopically before devouring them.

Estimated number of species : recent, 20 ; British, 0.

- Examples of Thalamita, Lissocarcinus, \&c.

Group 183.-Genus NEPTUNUS (De HaAn) and allies. Many of the species of this group are found on the high seas far from land. Note the clean-cut lines of the shield, the arms, and the swimming paddles in the frigate-like Neptumus pelagicus. The form of this oceancrab is a study in the art of combining prehensile efficiency with strength and speed.

Estimated number of species: recent, 20 ; British, 0.

- Examples of Amphitrite, Occanus crucifer, \&rc.

Group 184.-Genus PORTUNUS (FABricius) and allies. The British Swimming-crabs are known to fishermen by various local names, such as the common Shore-crab, the Velvet-crab, the Fiddler-crab, the Nipper, \&c. They 
are not first-rate swimmers, but are active and voracious, and from their omnivorous propensities have been termed the scavengers of the sea.

Estimated number of species : recent, 30 ; British, 12.

T Examples of Scylla, Polybius, Portumnus, \&c.

Group 185.-Family ERIPHID Æ (DANA).

Mr. Dana has established this family to include certain crabs distinguished by some important peculiarities connected with the respiratory apparatus. The small but pretty species of Trapezia, with bright porcellanous shields, are found amongst the branches and folia of living corals.

Estimated number of species : recent, 60 ; British, 2.

I Examples of Eudora, Pilumnus, Galene, Dometia, Geryon tridens, \&c.

\section{Family CANCERID正.}

Group 186.-Genus CANCER (Linnæus). The generic name Cancer has been retained to include the common edible crab, Cancer pagurus, and its allies. Several of the species grow to a large size. The gills of crabs are attached to the bases of the legs, and are contained in cavities protected by the sides of the carapace. An apparatus of fan-like appendages sweeps the water out of the gill-cavities by orifices in front, efferent canals, whilst a fresh supply of water rushes in from behind through orifices near the base of the fourth pair of legs, afferent canals, thus keeping up a constant circulation. Estimated number of species: recent, 10 ; British, 1.

१ Examples of about 6 species. 
Group 187.-Genus XANTHO (LEACH) and allies.

I Menippe gigas (M. EDwards) is probably the most powerful Crustacean : the pincers are worked by a muscular apparatus enormously developed, and must be capable of crushing with ease the shells of many bivalve Mollusca. Much variety in colour and sculpture is met with amongst the smaller generic forms.

Estimated number of species: recent, 50 ; British, 2.

T Examples of Chlorodius, Etisus, Daira, Acteodes, \&c.

Group 188.-Genus CARPILIUS (LeAcH) and allies.

Estimated number of species, 24 ; British, 0.

T $C$. coralinus, $C$. maculatus, and the rare $C$. signatus afford good examples of the smooth, convex, and highly-coloured shields which prevail in this group; Atergatis, Zozymus, \&c.

Section D.-Crabs with shielils more or less triangular, much narrowed in front $=$ Famille des OXYRHINQUÉES (MILNE EDWARDs).

Group 189.-Family PARTHENOPIDÆ. The species all live amongst rocks in moderately deep water; they move slowly and notwithstanding their grotesquely rugged aspect cannot be formidable except to animals much inferior in size to themselves. The single British species, the Strawberry-crab, is said to use its long arms in climbing.

Estimated number of species, 20 ; British, 1. 
Family MAIAD无.

Group 190.-Genus MAIA (LAMIARcK) and allies.

Estimated number of species, 40 ; British, 1.

I Maia squinado, the Thorn-back-crab, is not uncommon on the British coasts and in the Mediterranean. It was well known by the ancients, and was regarded by them as an emblem of wisdom.

Group 191.-Genus MITHRAX (LEACH) and allies.

Estimated number of species, 40 ; British, 4.

Groups 190 and 191 constitute the family MAIADE; most of the species in 191 have eyes on moveable foot-stalks, capable of being folded back and hidden in the channel of the orbit.

T Examples of Pisa, Hyas, $d c$.

Group 192.-Family INACHIDÆ. Spider-crabs.

Estimated number of species, 40 ; British, 6 .

T Leptopodia sagittaria is remarkable for the extreme length and slenderness of its rostrum and limbs. Such a form could exist only in a medium of nearly its own specific gravity. A closely allied species is the colossal Macrocheira Kaempferi of Japan, having by far the greatest span of any Crustacean. (See case over the east door.) Examples of Stenorhyncus, Eurypodius, and other genera. 


\section{Sebenteentb Cable $\mathfrak{C}$ ase.}

The Mark indicates specimens or other iliustrations exhibited in the Cases.

As far as the end of the Eleventh Table Case, and in the following portion of the series, the tablets have been completed; and from them occasionally a paragraph has been inserted in this Synopsis, but sparingly, to avoid unnecessary bulk.

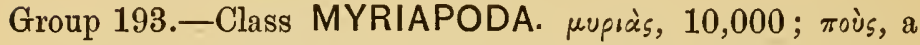
foot. The animals of this class have comparatively few segments when first hatched. The head is distinct, and in the Centipedes is armed with poisonous fangs. The remainder of the body is made up of nearly similar segments. Respiration is by tracheæ.

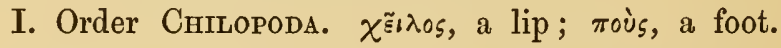
Centipedes : animals active, nocturnal, predacious.

II. Order Chilognatha. $\chi \tilde{s} ı$ ¿ jaw. Millipedes: animals tardy, vegetable feeders. About 500 species in this class are recognised by WALCKENAER.

I Examples of Scolopendra gigantea, Lithobius, Geophilus, Julus, Polydesmus, \&c. Small series of British Myriapoda, collected and presented by H. H. H. Euphorberia Brownii, a fossil of the Middle Coal-Measures, collected at Ravenhead, and presented by H. H. H. 


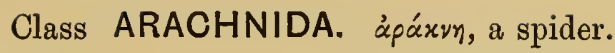

The following characters may serve to distinguish the animals of this class. Head and thorax amalgamated to form a cephalo-thorax; antennæ none, or modified into nippers; legs never more than four pairs; respiration aerial; transformations none, or indistinct.

The authorities most used have been C. L. Косн and Dr. C. W. $\mathrm{H}_{\mathrm{AHN}}$, "Die Arachniden," 16 vols. 8vo., and "Histoire Naturelle des Insectes Apteres," par M. le Baron Walckenaer et M. Paul Gervais, 5 vols. 8vo., Paris, 1847.

Group 194.-Sub-class ARACHNIDA-TRACHEARIA. Respiration by the skin or by respiratory tubes, trachece.

I. Order Podosonata. The Sea-spiders are found on Fuci, or under stones near low-water mark on the sea-coast, and are tardy creatures apparently made up grotesquely of little more than jointed limbs. Pycnogonum, Nymphon, \&c.

II. Order Acarina. Water-bears, Tardigrada, animalcules found in wet moss, \&c.; Mites, Acari; Water-mites, Hydrachnida; the Itch-acarus, Sarcoptes; the harmless parasite on the face, Desmodex; and the Tieks, Ixodes.

III. Order Adelarthrosomata. «̌ő̀nos, concealed; äptpov, a joint; $\sigma \tilde{\omega} \mu \alpha$, a body. Harvest-spiders, Phalangida; the Book-scorpion, Chelifer; and the venomous Galeodes of the family Solpugida.

The biology of this group, of which WaLCKENAER describes about 450 species, when it shall have been fully investigated must prove to be deeply interesting, because of the extreme divergency amongst its con- 
stituents. If the segregation be natural, $i . e$. if the genealogical affinity be real and close, great indeed must have been the influence of habits and circumstances under which a Galeodes and a Desmodex, a Hydrachna, a Chelifer and a Pycnogonum have been evolved from a common and not very remote ancestor.

\section{Sub-Class ARACHNIDA-PULMONARIA.}

Respiration by pulmonary sacs, with or without respiratory tubes; cephalothorax more or less distinct from the abdomen; eyes six, eight, or twelve in number.

Group 195.--Order PEDIPALPI. Scorpions and allies. Head and thorax amalgamated; abdomen distinctly segmented. Estimated number of species, 93 (WALCKENAER).

T Examples of about 22 species of Scorpions, including the Black or Rock-scorpion of Africa, the most formidable of the family. Several species of Phrynus: observe in the largest example, which is probably of an undescribed species, the extreme length and slenderness of the many-jointed tarsi of the first pair of legs. Examples of Thelyphonus, a hateful-looking but probably not renomous animal, of which species are found in Mexico, Brazil, India, Java, and other hot countries.

Group 196.-Order ARANEIDA. Spiders. Head and thorax amalgamated; abdomen not segmented; eyes six or generally eight. The life history of spiders is deeply interesting; that of the British species has been well told by Mr. E. F. Staveley. 
Space is here deficient, but some of the more remarkable forms are exhibited, including Gasteracantha and Acrosoma, with bodies armed with long spines and glittering during life with brilliant metallic colours. Estimated number of species, 1220 (WALCKENAER); British, 303 (BLACKWALL).

T Small series of British Spiders presented by $\mathrm{J}$. Blackwall, F.L.S., author of "A History of the Spiders of Great Britain and Ireland."

Upper Compartment.

About 14 species of Mygale, $\mu \nu \gamma \alpha \lambda \tilde{\eta}$, a Field-mouse ; tubular nests of Mygale, shewing the trapdoor; female Mygale, with egg-cocoon, \&c.

\section{Class INSECTA.}

Head, thorax, and abdomen distinct; antennæ a single pair; three pairs of legs borne on the thorax.

The species included in this", wondrous class have been estimated at 160,000 in number, which is about equivavalent to the sum of the species in the whole of the rest of the Invertebrate Animals, together with the Fishes, Reptiles and Amphibians, Birds and Mammalia, with all the known species of plants in addition. In other words, Insects constitute about one-half of the species included in the Animal and Vegetable Kingdoms. (Mr. Benthan's Presidential Address to the Members of the Linnæan Societr, 1871.)

The chief orders of the class have long been pretty well established on characters mainly derived from the organs of flight; but all attempts to collect the orders into higher divisions have hitherto been unsatisfactory. By far the most important scheme divides the class into 
three sub-classes. I. Ametabola; 'Transformations absent. II. Hemingetabola; Transformations incomplete. III. Metabola; Transformations complete. But the advantage of this classification has in the present instance been relinquished as incompatible with the integrity of the Orders. Objectionable on the same ground are the older divisions: I. Haustellata ; Insects with sucking mouths. II. Mandibulata; Insects with biting jaws. Groups 197-222 chiefly illustrate the former, groups $223-240$ the latter of these divisions.

The order of the groups corresponds nearly with the arrangement adopted in the "Introduction to the Modern Classification of Insects," by J. O. Westwood, F. L. S., 2 vols. 8vo., 1839; one of the best books on a subject of natural history that has ever appeared in the English or in any other language.

After some labour and much thought, the writer can only come to the conclusion that the disadvantages of a linear arrangement are nowhere more troublesome than amongst the manifold affinities in this most instructive class, Insecta.

Order HETEROPTERA. "̈ँ $\tau \varepsilon \rho o s$, different; $\pi \tau \varepsilon p o \nu$, a wing. Insects having their fore-wings chitinous or leathery towards the base, and membranous towards the apex. Estimated number of species: total, 1350 (F. WALKer, 1873); British, 354 (J. W. Douglas).

Group 197.-HETEROPTERA-HydRocoRISA. Ǔ̉ $\delta$, water; xópls, a bug.

This portion of the Heteroptera is made up of aquatic insects of which the species are not numerous. 
T Examples of Water-scorpions, Nepa; Boat-flies, Notonecta; and of the only truly oceanic genus of insects, Halobates, specimens presented by Capt. Borlase. Observe the arrangement of the eggs on the back of Zaitha; how were they placed there?

Small series of British species collected and presented by $\mathrm{H}$. H. $\mathrm{H}$.

The division Ametabola here introduced, consisting of insects which undergo no transformations, includes three orders of which the species are all of small size :

I. Order Anoplura. Lice, with sucking mouths. Pediculide.

II. Order Maliophaga. Bird-lice, with biting jaws. Philopterc, several species of which are said to be found on the same animal.

III. Order Thysanura. Spring-tails, Podura, Lepisma.

WaLCKEnaer describes 300 species of the first two orders, and 106 of the third. The British species of the first two orders have been described by $H$. Denny; those of the last have appeared very recently in a beautiful monograph by Sir JoHN LubBock.

Group 198.-HETEROPTERA-GEOcoRISA. $\quad \gamma \tilde{\eta}$, the earth ; xopis, a bug. Notwithstanding the bad reputation attached to this group by reason of its including the common House-bug and some exotic species far more severely noxious, we here meet with curiously fantastic shapes and brilliant contrasts of colour. The British species though small are frequently beautiful, and have been described in an excellent monograph by $\mathrm{J}$. W. Douglas. 
T Observe the foliaceous expansions on the legs of Viactor, the protective mimicry in Phloea, and the prismatic reflexions in some of the Scutellerida.

Small series of British species presented by J. W. Douglas.

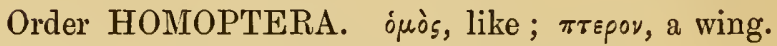
Wings four, entirely membranous and deflexed.

Group 199.-Family FULGORID曆. Fulgor, brightness; and allies.

I Examples: Lantern-flies, Fulgorida ; the China Wax-insect, Flata; Frog-hoppers or Cuckoospit-insects, Cercopida; Plant-lice, Aphida; Scale-insects, Coccide; Cochineal-insect, Coccus cacti; Shell-lac-insect, Coccus lacca.

Observe the curious modifications of the "Lantern"; the waxen plumes in Lystra; the extravagant development of the prothorax in some of the exotic Cercopidle.

Small series of British species presented by F. W. Douglas.

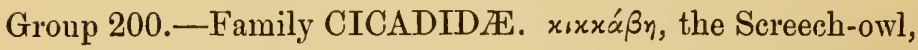
in allusion to its shrill note. Illustrated by about 36 species, including representations of Polyneura, Gceana, and Dundubia imperatoria, the largest species in the group. Observe the instrument by which the male Cicada emits its loud note; it is a tense membrane on its sides near the base of its wings, and is best seen in C. saccata, from Australia.

A single species is found in Britain, where it is by no means common. 
Group 201.-Order DIPTERA. סis, twice; $\pi \tau \varepsilon p o v$, a wing. Wings two ; the lower pair of wings are replaced by a pair of slender filaments clubbed at the tip, called halteres or poisers. No two-winged fly has a sting.

Estimated number of specics, 24,000 (Bentram); 5220 species are described in "Histoire Naturelle des Insectes Diptères," J. MACQUART, 11 vols., 1835-1855. The British species exceed 2000; Insecta Britannica, Diptera, F. WALKER, 3 vols., 1856.

I Examples: Meat-flies, Muscida; Gnats and Mosquitoes, Culicida ; Long-legs, Tipulide; House-flies, Anthomyia; Hoverers, Syrphide; Gad-flies, Tabanida. The African Tsetze, Glossina morsitans, is a desideratum.

Fleas, Pulicida, are inserted in this group because of their resemblance to certain two-winged flies found near the roots of trees in woods, Mycetophilida, the larvæ of which infest various species of Agaricus and other Fungi.

Observe the eyes in Diopsis set at the ends of footstalks; the hymenopterous aspect of Mydas giganteus and the extended proboscis of Pangonia, capable it is said of piercing the hide of cattle while the insect is still on the wing.

Series of British species presented by Benjamin Cooke.

Order LEPIDOPTERA. $\lambda \varepsilon \pi i s$, a scale; $\pi \tau \varepsilon \rho o \nu$, a wing. Wings four, covered on both sides with minute imbricated scales. Estimated number of species, 24,000 (Bentham).

The works used in naming and arranging the series were numerons. Those of especial service were 
"Papillons Exotiques," Craner and Stoll, 5 vols. 4to.; "Sammlung Europaischer Schmetterlinge," J. Hüвner, 9 vols. 4to.; "Genera of diurnal Lepidoptera," DoubleDAY AND WeSTTOOD, 2 vols. imp. quarto; and the works of W. C. Hewitson.

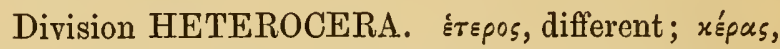
a horn. This division includes all the insects of the order except Butterflies.

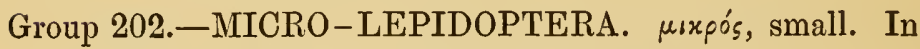
this group are included all the Heterocera below the Noctuc; Pyralidina, Tortricina, Tineina, Pterophorina, and Alucitina. More than 300 species are described and figured by H. T. StaINTon in his monograph of Tineina, 13 vols. 8 vo. The British species representing the group exceed 1130 ; the exotic species are in proportion less numerous than in other groups.

Group 203.-NOCTUÆ-GENUINÆ. Estimated number of species: British, more than 300; European, 800.

T Examples of a few exotic and about 80 selected species of British Noctuæ. Observe the diversity elaborated within the limits of conspicuous similarity.

Group 204. - NOCTUÆ-LIMBATÆ. limbus, a border. Observe the British species of Catocala, including $C$. Fraxini; also the Owl-moth of Brazil, Thysania Agrippina, so coloured as easily to escape notice when resting on the bole of a tree. The specimen exhibited measures more than eleven inches across the wings. 


\section{Eightecnth $\mathbb{C}$ able $\mathbb{C a s e}$.}

The Mark 9 indicates specimens or other illustrations exhibited in the Cases.

Group 205.-GEOMETRINA. $\gamma \tilde{\eta}$, the earth; $\mu$ śrpov, a measure. The name alludes to the mode of progression adopted by the larvæ, which are called loopers because in moving they. alternately take the form of the Greek letter $\Omega$ and extend themselves at full length.

The females of certain species are without wings. Geometre, of which about 270 kinds inhabit Britain, are sometimes seen in the cold grey light of a winter evening, but more characteristically they are the butterflies of the summer twilight. Whilst the Noctuce and other more robust moths, passing swiftly by, seem always in haste, these slender and delicately coloured insects flutter leisurely along the hedge-side in the gloaming, apparently in a condition of perfect enjoyment.

Upper Compartment.

Specimens of preserved larvæ, showing protective mimicry.

Section BOMBYCINA. $\beta$ ó $\mu$ $\beta \xi$, the silk-worm.

Group 206.-Genus SATURNIA, and allies. This group includes amongst its coustituents upwards of 40 silkproducing moths, the larvæ of which secrete the silk in two large intestine-like vessels which unite at the mouth in a common tube called the spinneret; through this tube is ejected the secretion which, as soon as it comes in contact with the air, hardens into a shining fibre known as silk.

Observe the configuration of the shaded pattern in Brahmea and the talc-like spot in Attacus Atlas. 


\section{Upper Compartment.}

The Ailanthus Silk-moth, Attacus Cynthia, Cocoons, Silk, \&c.; also Cocoons and Silk of the Tusseh and various other Silk-worms, presented by F. Moore.

Group 207.-Genus ARCTIA and allies. Observe examples of the exotic genus Histia from Northern India and Java, the species of which in outline and colouring closely resemble butterflies. For an account of mimicry in Insects see the Tablet. The group is illustrated by 18 British species.

Group 208.-PSEUDO-BOMBYCES. The Swifts, Lappets, and Prominents, include some of the most rare and beautiful British moths. Of these about 40 species are exhibited.

Upper Compartment.

Specimens of a Fungus, Torrubia Robertsii, on the larvæ of Hepialus from New Zealand; also of Torrnbia militaris on pupæ of moths, collected at Rainhill and presented by H. H. H. Prepared larvæ of moths.

Group 209.-Family URANIID Æ and allies. Species of Urania are frequently seen near the rivers of Brazil flying in a certain direction, and following one another in rapid succession for several days together; yet not one is seen to return. These insects resemble butterflies, but are distinguished by the antennæ which are not clubbed, and by the chrysalis which is not angular. Observe especially the very rare and beautiful Urania Riphceus, a native of Madagascar, and the scarcely less beautiful Nyctalemon.

In this group also are included the Burnets, Clearwings, \&c., Zygenidee and other Families: amongst 
them may be noted Glaucopis caudata, with an appendage resembling an ovipositor; it is probably a mimic of an associated Hymenopterous insect.

Group 210.-Family SPHINGIDÆ. $\sigma \phi i \gamma \xi$, the sphinx. The name alludes to the larva, which frequently carries its head erect. Note the artistic correspondence between the colour patterns and the very peculiar outlines of the insects in this group.

Upper Compartment.

Specimen of S. Carolina, with extended proboscis.

Division RHOPALOCERA. pó̄ $\alpha \lambda 0 v$, a club; xépas, a horn. This division inclndes all the Butterflies, properly so called.

The colour patterus of Butterflies appear to be derived through various modifications from two very simple type patterns, wrought with one or both of two kinds of scales.

A. First Type-pattern. Wings having a pale ground with lines composed of dark seales along the veins. Example: Aporia crategi. British.

B. Second Type-pattern. Wings having a pale ground with an orange or red blush occupying the central area. Gonepteryx Cleopatra European.

There are also two kinds of scales:

C. Scales coloured by Pigment. White, Yellon Brown, Black, Red, \&c.

D. Irtdescent Scales, deriving their colour chiefiy from the striation of their surface. Gold, Sil. ver, Blue, Green, Amethyst, Crimson, \&c.

Modifications :-

$\mathrm{A}^{\prime}$. Dark lines attenuated, visible only at the tip and there expanded. Pieris Brassica. British. 
$\mathrm{A}^{\prime \prime}$. Dark lines expanded, forming patches and scallops. Arge Galathea. British.

$\mathrm{A}^{\prime \prime \prime}$. Dark lines expanded, forming a blackish area, and leaving the pale ground visible only in spots or markings. Thymele alveolus. British. Lasiommata Egeria. British.

$B^{\prime}$. Blush, occupying a space near the tip. Anthocaris cardamines. British.

$\mathrm{B}^{\prime \prime}$. Blush, occupying nearly all the area of the wings.

Note.-Even where, as in Euplaa Treitschlei, only a small spot or two of white is shown on the wings, it is pretty plain that the ground colour of the wing is white, almost wholly obscured by a greater development of the dark scales belonging to the veins. The iridescent scales, except when forming metallic markings, as on the under side of the Fritillaries, are gen era mingled with dark scales (rarely with the pale groun scales), the edges of the areas in which they prevail being shaded off, as in Apatura Iris. British.

The Common Admiral, Pyrameis Atalanta, is an example of the combination of $\mathrm{A}^{\prime \prime \prime}$ with $\mathrm{B}^{\prime \prime}$. Wherever the black does not extend, is shewn the red blush, which does not however reach quite to the tip of the fore wing, for there, apertures in the black show the white or pale ground colour in spots. The New Zealand Admiral, Pyrameis gonerilla, on the under-side of the fore wing indicates plainly that the true character of the red area is that of a blush on a pale ground. The subject is more fully treated by the Writer in a paper which appeared in the Quarterly Journal of Science, for July, 1868, and has been honoured with a favourable notice by Mr. DARWIN (Descent of Man, vol. ii., p. 134, note). 
Group 211.-Family HESPERIDF. Skippers. A rustic type of form and colouring characterises the insects of this group from all parts of the world. Estimated number of species : British, 7 ; exotic, 650 .

Group 212.-Families ERYCINID王, Humming-bird Butterflies; and LYCÆNID无, Copper's, Blues, Hairstreaks. The Erycinide are chiefly from Tropical America: amongst them are counterparts in miniature of most of the chief types amongst the Butterflies. Do these insects appreciate their own beauty? It is a beauty distinguished not less by its superlative richness and variety than by the absence of all incongruous embellishments. Such an insect as Helicopis Cupido is to an eye not æsthetically trained, what a scherzo of Beethoven's is to an unmusical ear. In approaching the question how such a result has been produced through evolution, the present case differs not in kind from that of any other living thing; but the difficulties associated with the hypothesis of evolution, when regarded as working only by means of natural selection, are in such an instance as this conspicuously displayed.

Estimated number of species : British, 19 ; exotic, 750.

Group 213.-Family SATYRIDE and allies. Meadow-russet Butterflies. Note the transparent wings with one azure spot in Hetera Esmeralda. Estimated number of species : British, 11 ; exotic, 450.

Group 214.-Family MORPHID $\mathbb{E}$ and allies. Glory of Brazil Butterflies. The typical kinds are all found in Tropical America : some species frequent open places in forests, flying with a slow flapping motion over the tops of the low herbage: other's sail majestically round the tops of trees and are difficult to capture. Observe the resplen- 
dent Morpho Cypris from Columbia, and the opaline sheen of Morpho Ganymede from Bogota. Estimated number of species, 100 .

FAMILY NYMPHALIDE. vú $₫$, a bride.

Group 215. - Genus APATURA and allies. The group includes Butterflies allied to the Purple Emperor found in Britain. Note especially Nymphalis Jason, from Southern Europe. Estimated number of species: British, 2 ; exotic, 400.

Upper Compartment.

T Examples of mimicry of leaves, Kallima Inathis and Hebonoia Glancippe. Earlier and later broods of the same Butterfly, P. prorsa and Levana.

Group 216.-Genus VANESSA and allies. Note several exotic species corresponding with British forms, e. $g$. the New Zealand Admiral, Pyrameis gonerilla.

The caterpillar of a Butterfly is an embryo furnished with the means of locomotion and mastication. The stages which the bird passes through in the egg, and the animal in the fœtus, are attended in the insect by the power of seeking for and devouring food.

Upper Compartment.

Preserved larvæ, and drawings of eggs.

\section{dimetently Cuable ciase.}

Group 217.-Genus ARGYNNIS (FABRICIUS) and allies. Fritiluaries. Note Agraulis moneta, Mexico, so called from the silver-like plates on its under side. Estimated number of species: exotic, 150 ; British, 9.

Group 218.-Family HELICONID正 and allies. The beautiful Heliconide are from Tropical America: when crushed they emit an offensive odour, which is said to protect them from the attacks of birds. The group 
includes the Acraida from Africa. Estimated number of species: exotic, 350 .

Group 219.-Family DANAID瓜 and allies. The species are natives of the Eastern Hemisphere. Note especially the two species of Hestia from Java. Estimated number of species: exotic, 110.

Upper Compartment.

Case with examples of the black-veined-white pattern from six distinct families of butterflies, and one of moths.

Group 220.-Family PIERIDE. Whites. Note the European and Mexican species allied to the Brimstone Butterfly of this country ; also the mimicry of the Heliconide in the females of certain species. Estimated number of species : exotic, 450; British, 10.

Upper Compartment.

Pairs of Butterflies shewing a remarkable difference between the male and female of the same species; preserved larvæ and magnified drawings of eggs.

Family PAPILIONIDÆ.

Group 221.-Genus PAPILIO and allies. Swallow-tailed Butterflies. For the Linnæan divisions of the Butterflies into Equites, Danai, Plebeii, \&c., see the Tablet.

Upper Compartment.

Case with specimens of Papilio Vertumnus, presented by H. J. CAUTY. A chair is placed near, by the aid of which $P$. Vertummus may be seen by looking down upon it from above; whence the carmine spot on the lower wing appears of a pale amethystine hue. 
Group 222.-Genus ORNITHOPTERA, and allies. öpris, a

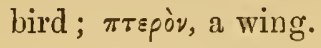

These royal insects are found chiefly in the Molucca Islands and in New Guinea. Observe the difference between the male and female in $O$. Crosus and O. Aruana; also the extended palpi in Teinopalpus, a native of the higher ranges of the Himalayas, on the borders of Assam. Estimated number of species, 20.

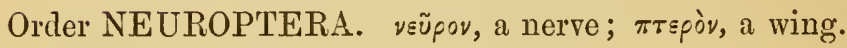
Group 223.-NEUROPTERA in part.

I May-flies, Ephemerida; Ant-lions, Myrmeleonide; Lace-wings, Golden-eyes, Hemerobiide; two examples of the exquisitely fantastic forms characteristic of the genus Nemoptera, N. Coa and N. Lusitanica; Corydalis, the most savage looking of all insects; Winged, worker, and soldier forms of Termitide, the so-called White Ants. The group also includes the order TrIChoptera (KIrby), = the Caddice-flies, Phryganeide, and the order Thysanoptera $\left(\mathrm{H}_{\text {ALIdAY }}\right)=$ Thrips. Series of British representatives of the group, presented by BeNJAMIN Cooke. Wing of a large insect, beautifully preserved in a nodule of ironstone, from the middle coal-measures, Ravenhead; collected by the writer, and referred to the genus Corydalis. Mr. B. Cooke, after a careful examination of the fossil, believed it to represent the basal portion, abont one-third only, of the fore-wing of a Nothochrysa. 
Upper Compartment.

Larva of Ant-lion; female of White Ant.

Group 224.-NEUROPTERA ODONATA. Dragon-flies, Libellulide.

Note the extraordinary length of body in Lestes Lucretia, from the Cape of Good Hope; also the species from Borneo. British series, B. Cooke and F. BrockHoles.

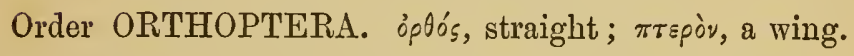

Group 225.-Family PHASMID无. $\quad \phi_{\alpha}^{\prime} \sigma \mu \alpha$, a spectre.

Walking-stick and Spectre insects, vegetable feeder's, chiefly found in India, China, South America, and Australia. Observe Lonchodes virgeus, which has the longest span of any known insect; also three species of genus Phyllium, the Walking-leaf.

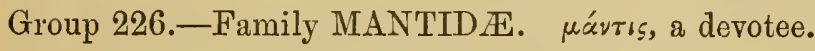

Generally distributed in warm climates; rapacious insects, assuming, whilst on the watch for prey, attitudes alluded to in the names Mantis religiosa, Mantis oratoria, \&c.

I About 24 species illustrate the group.

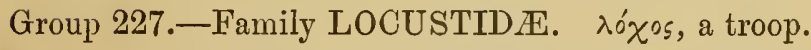

Tree-locusts. Rarely gregarious. Most of the continental authorities agree in applying the name "Locust" to the species in this group, distinguished by their long, slender antennæ, and by the sabre-like ovipositor of the female. Either the Greek or the Latin derivation (locus ustus, a scorched place) of the name would 
seem to apply more appropriately to the gregarious and migratory species included in the following group.

Observe the closeness of the resemblance between several species of Locusts and the leaves of trees in various stages of decay. This mimetic perfection may be regarded as the result of progressive improvements on the part of the assailants, as well as on the side of the species protected by disguise; individuals on the one side becoming more and more mimetic, and on the other (that of their enemies) more and more able to penetrate through the assumed disguises. - (The Naturalist in Nicaragua, by Thomas BeLt, 1874.)

Group 228.-Family ACRIDIIDÆ. «ँxprs, the grasshopper. Migratory Locusts, Grasshoppers, \&c. The ravages for which these insects have long been notorious have not been confined to a single country; nor have they always been committed by the same kind of locust. Africa seems to have suffered most frequently and severely, but Europe, North and South America, and the East have from time to time been subject to their visitations.

Series of British species, presented by B. Coors.

\section{Cloventictly Cable case.}

The Mark indicates specimens or other illustrations exhibited in the Cases.

Group 229.- Families ACHETID 2 and BLATTID正. Crickets, Achetida. ’’ $\chi^{\prime} \varepsilon \eta \xi$, an utterer of shrill sounds. 
Note the form of the fore-legs, constructed for burrowing, in the Mole-cricket, Gryllotalpa vulgaris.

Cockroaches, Blattide. The British species are of small size : the common Cockroach which infests houses, Blatta Orientalis, is supposed to have been introduced from the Levant.

The order Euplexoptera = Earwigs, Forficulida, derives its name from the wondrous manner in which the ample wings are folded and hidden under the tiny wing-sheaths of the insect.

The order Strepsiptera = Stylops, parasitic on Bees, closely allied to the Beetles, would be here illustrated, but the insect is yet a desideratum.

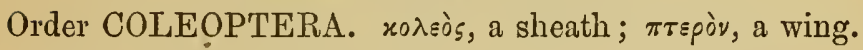
The number of species in this order, as estimated by Mr. Вемтнам in 1871 is 90,000 . Works of especial service in naming and arranging the series were, LACoRDAIRe, Genera des Coleoptères, 9 vols., Paris, 1859; Ouivier, Entomologie, 6 vols. 4to.; Gory et PercheRoN, Monographie des Cétoines.

Mrost of the groups include a small series of selected British species presented by B. Coore, or collected in the neighbourhood of Liverpool by H. LoNGdet Higains.

Group 230.-Divisions EUPODA, PSEUDOTRIMERA, HETEROMERA.

Examples of Tortoise-beetles, Cassidida ; Turnipfly, Phyllotreta; Lady-birds, Coccinellida; Meal-worm-beetle, Tenebrio; Cellar-beetle, Blaps; Oil-beetle, Meloë; Blister-beetle, Lytta, \&c.; also of the division BracheLytra.

Estimated number of British species, more than 1,000. 
Division LONGICORNES. Long-horned Beetles.

Group 231.-Families LAMIAD必, LEPTURID $A$, and allies. The group is illustrated by more than 60 exotic species, and by many of the 40 British species. Note the tufted horns in some examples of Lamia.

Upper Compartment.

Series of Long-horned Beetles, collected in Madagascar, and bequeathed to the Museum by W. T. GerRard.

Group 232.-Families CERAMBYCID无, PRIONIDÆ, \&c. The Family Cerambycida, as established by Linneus, included most of the Long-horned Beetles, now distributed in more than 1,300 genera. British representatives of the group, 12 species.

T Psalidognathus Friendii, from Columbia.

Group 233.--Division RHYNCOPHORA. ṕ̀y $\gamma 0$ s, a snout; $\phi$ spw, I carry. Weevil-beetles. The space allotted to exotic forms is occupied by more than 80 species illustrating the principal types. British species, 500; exotic very numerous, distributed in about 900 genera.

Note the series of Diamond and Gold-patch Beetles, Entimus, Cyphus, Eupholus, \&c.

Group 234.-Divisions STERNOXI and MALACODERMI. Examples of Buprestida, remarkable for their gorgeous colours; Skip-jacks and Fire-flies, Elaterida, in certain species of which spots becoming luminous in the dark may be seen on the hinder angles of the thorax; the Glow-worm, Lampyris, \&c. British species, 200.

Group 235.-Family CETONIID $Æ$ and allies. Goliath Beetles, Rose-chafers, Cock-chafers, \&c. British 
species, 15. The exotic species are very numerous; about 90 are exhibited.

I Mycteristes Cumingii, Philippines, and seven species of Ceratorhina, all from Africa.

Group 236.-Family SCARABEIDE and allies. Specimens of the Sacred Scarabæus, Ateuchus sacer; Dumbledor, Geotrupes, \&c. British species, 62.

Note the wondrous horn-like extensions of the thorax in Chalcosoma Atlas, and the prodigious forelegs in Euchirus longimanus.

Upper Compartment.

Ancient Egyptian Scarabæus.

Group 237.-Families LUCANID艮, DYTICID无, and others. Carrion-beetles, Necrophaga; Stag-beetles, Lucanide; Predaceous Water-beetles, Hydradcphaga, \&c. British species, 600.

I Chiasognathus Grantii, Chili, \&c.

Group 238.-Division GEODEPHAGA. Predaceous Landbeetles. Tiger-beetles, Cicindelide; Carabida; Bombardier-beetle, Brachinus crepitans, \&c. British species, 350.

I Mormolyce Phyllodes, Java; Manticora scabra, Africa, \&c.

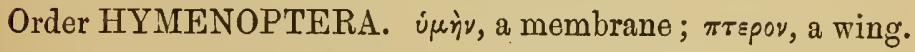

The species of Hymenoptera have been estimated at 25,000, but no work has appeared on the whole of the order comparable with the great work of LACORDAIR on the Coleoptera. In this country, collectors of Butterflies and of Beetles are more numerous by many times than collectors of the Hymenoptera; yet these, in their biology, are far more interesting than any other order of insects. 
Group 239.-Divisions TEREBRANTIA and ACULEATA in part. Saw-flies, Tenthredince; Gall-flies, Cynipida; Ichneumons, Wasps, Hornets, \&c.

More than 250 kinds of galls have been described, many of which are formed by Cynipida on the roots, twigs, or leaves of the oak. The minute particle of virus injected by the insect when depositing its egg seems to possess properties capable of compelling the growthforce of the oak to develop cells constructing an oak-apple, a nut-gall, a leaf-spangle, or some other form of nidus best adapted to the habits and necessities of the tiny parasite : a correlation truly wondrous. Galls are known to be injurious to oak-trees; can their presence be associated with some compensative advantage?

Note the enormous length of the ovipositor and sheath in Pimpla atrata. British series, chiefly local, deposited by the Royal Institution, Liverpool.

Upper Compartment.

Nests of Social Wasps ; Galls and Oak-apples, with the Gall-fly Cynips, together with specimens of Allantus and Chalcis, from the same gall.

Group 240.-Family FORMICID $æ$ and Division MELLIFERA. Ants and Bees. About 180 British species of Bees have been described.

Mr. BELT's work on Nicaragua contains a large amount of very interesting information on the habits of ants, especially those of a species of stinging ant which finds both food and a home 
in the hollow thorns of an Acacia, and in return protects the tree from the formidable attacks of leaf-cutting ants. The Ecitons, or foraging ants, he regards as being in intelligence at the head of all the insect tribe.

I Male, Female, and Worker of the Hive Bee, British series of Bees, chiefly collected in the neighbourhood of Liverpool, by H.H. H., and deposited by the Liverpool Royal Institution.

\section{Supplementary Note to Group 11.}

The following Extract is from an address delivered by my fiiend Professor Allman, F.R.S., to the Biological section of the British Association, 1873.

"Let us take an example in which these two principles seem to be illustrated. In rocks of the Silmian age there exist in great profusion the remarkable fossils known as Graptolites. These consist of a series of little cups or cells arranged along the sides of a common tube, and the whole fossil presents so close a resemblance to one of the Sertularian hydroids which inllabit the waters of our present seas as to justify the suspicion that the Graptolites constitute an ancient and long since extinct group of the Hydroida. It is not, however, with the proper cells, or hydrothecx, of the Sertularians that the cells of the Graptolite most closely agree, but rather with the little receptacles which in certain Sertularinæ belonging to the family of the Plumularidæ we find associated with the-hydrothecæ, and which are known as "nematophores." A comparison of structure, then, shows that the Graptolite may, with considerable probability, be regarded as representing a Plumularia in which the hydrothecæ had never been developed, and in which their place had been taken by the nematophores.

"Now it can be shown that the nematophores of the living Plumularidæ are filled with masses of protoplasm which have the power of throwing out pseudopodia, or long processes of their substance, and that 
they thus resemble the Rhizopoda, whose soft parts consist entirely of a similar protoplasm, and which stand among the Protozoa, or lowest group of the animal kingdom. If we suppose the hydrothecre suppressed in a Plumularian, we should thins nearly convert it into a colony of Rhizopoda, from which it wonld differ only in the somewhat higher morphological differentiation of its coenosare, or common living boind by which the individuals of the colony are organically connected. And just such a colony would, under this view, a Graptolite be, waiting only for the development of hydrothecre to raise it into the condition of a Plumularian.

"Bringing, now, the Evolution lhypothesis to bear upon the question, it would follow that the Graptolite may be viewed as an ancestral form of the Sertularian hydroids, a form having the most intimate relations with the Rhizopoda, that hydranths and hydrothecæ became developed in its descendants, and that the Rhizopodal Graptolite became thus converted in the lapse of ages into the hydroidal Sertularian.

"This hypothesis would be strengthened if we found it agreeing with the phenomena of individual development. Now such Plumularidi as have been followed in their development from the egg to the adult state do actually present well-developed nematophores before they show a trace of hydrothece, thus passing in the course of their embryological development through the condition of a Graptolite, und recapitulating within a few days stages which it took incalculable ages to bring about in the palæontological development of the tribe."

\section{NOTE.}

Six tiers of drawers occupy each side of the block supporting the table-case, and not four tiers as indicated by the frontispiece. 


SMITHSONIAN INSTITUTION LIBRARIES 